\title{
Evaluating Barriers and Drivers to Sustainable Food Supply Chains
}

\author{
Siyavash Mohseni, ${ }^{1}$ Komeyl Baghizadeh $\mathbb{D D}^{2}{ }^{2}$ and Julia Pahl $\mathbb{1 D}^{3}$ \\ ${ }^{1}$ Department of Industrial Management, Kharazmi University, Tehran, Iran \\ ${ }^{2}$ Department of Industrial Engineering, Kharazmi University, Tehran, Iran \\ ${ }^{3}$ SDU Engineering Operations Management, Department of Technology and Innovation, University of Southern Denmark, \\ Odense, Denmark \\ Correspondence should be addressed to Komeyl Baghizadeh; komeil.baghizadeh@gmail.com
}

Received 13 October 2021; Revised 9 January 2022; Accepted 18 January 2022; Published 22 February 2022

Academic Editor: Stefania Tomasiello

Copyright (C) 2022 Siyavash Mohseni et al. This is an open access article distributed under the Creative Commons Attribution License, which permits unrestricted use, distribution, and reproduction in any medium, provided the original work is properly cited.

\begin{abstract}
Today, with the daily increase in population, the demand for agricultural and/or, in general, food products continuously raises and so does the natural resources consumption which induces challenges to the supply chain management of important food products. In the present study, drivers as well as barriers of the agriculture sustainable supply chain are identified and ranked with the help of multicriteria decision-making (MCDM) techniques. We identify six drivers and seven barriers with the help of experts' opinions in the field and apply ranking methods including TOPSIS-AHP, AHP, and COPRAS-AHP as well as Borda rule and Copeland method to merge the ratings. The results highlight that the economic dimension of sustainability is more important than the environmental and social dimension. Distrust of consumers, lack of understanding and awareness of managers, and performance appraisal problems were found to be the most important barriers. Furthermore, informing the community by the media, entering the global market, exporting products, and producing sustainable products as a competitive advantage were identified to be the most important drivers. The study also shows that public awareness and demands can push the food supply chains toward sustainability goals with the cooperation of governments and suppliers.
\end{abstract}

\section{Introduction}

Population growth raises the demand for food and the consumption of natural resources. The same is valid for growing emerging economies that have unprecedentedly improved the quality of life across the world while putting exceptional pressure on natural resources and the environment [1]. This influences the provision or production and supply of food and reveals problematic factors including food price variations, climate change induced growth problems, food waste, and food security, as well as inadequate governmental policies $[2,3]$. According to the Food Summit Meeting in 1991, food security is the case when the entire world population has physical, social, and economic access to sufficient healthy and nutritious food at any time for the conduct of active and healthy lives [4]. To meet demands for healthy food, managers and politicians need to foster agricultural sustainable supply chains [5]. We understand sustainability as the quality that permits to preserve, to keep, and to maintain something [6] and, according to the World Commission on Environment and Development (WCED), using resources to meet the present needs without compromising the ability of future generations to meet their own demands. Accordingly, economic, environmental, and social dimensions are identified to evaluate aspects of a sustainable environment [7] where all three dimensions need to be addressed if something can be labeled sustainable. This involves a variety of economic, environmental, and social objectives [8] which companies need to equilibrate in order to attain higher levels of performance not only with respect to sustainability. Many trade-offs exist between the dimensions and objectives with different drivers 
and barriers that decision makers need to be aware of especially regarding food items [9]. These are essential to maintain life, but subject to deterioration, thus delicate and susceptible to wastage.

The food industry is one of the largest manufacturing sectors in many developing and developed countries [10]. Although food production and distribution systems are generally organized in efficient ways, gaining and maintaining sustainable supply chains is challenging also due to the consumer behavior and habits to consider food as a lifestyle. This induces a lack of awareness of interrelated aspects of resource consumption of food with respect to water and energy [11]. Poorly managed food supply chain stages, e.g., production, processing, transportation, and consumption, strongly affect food waste and thus sustainability [11]. By incorporating practices that relate to the development of trust and the quality of relationships inside and outside organizations, companies can enhance their performance and become more sustainable [12]. However, this is a long-term strategy that needs to be emphasized and pursued by (top) management. It further requires investments that can signify a hindering point especially for smaller companies.

Quite some contributions have been made to achieve comprehensive ideas on the identification of drivers and barriers on adopting sustainability-oriented practices [13]. These further propose solutions to tackle the barriers. Moreover, a number of drivers are mentioned that can foster sustainability in supply chains, such as appropriate managerial approaches, governmental policies, and customer awareness [14].

Concerning mathematical formulations for sustainable food supply chains, a major part of optimization models only considers single objective function mostly minimizing overall costs. However, multicriteria decision-making approaches (MCDM) are especially suited to capture aspects of sustainability including economic, environmental, and social dimensions in more detail for optimization. Such approaches are proposed by, e.g., Kumar et al. [15].

The present study adopts MCDM techniques to identify and rank drivers and barriers of the implementation of sustainability measures within food supply chains focusing on rice as food product. Rice is a strategic product not only in Iran, but worldwide as the world's second most important cereal after crop (see https://www.statista.com/topics/1443/ rice/). Countries in and surrounding Asia have traditionally the highest share in the worldwide rice production. Besides, it has a critical role in the Iranian economy. According to the Agricultural Office of the Statistical Center of Iran, Mazandaran Province accounts for the largest portion of total rice production rate in Iran with 38\%. Our study shows that economic barriers are the most limiting factors for implementing sustainability measurements for companies. The economic dimension of sustainability is more important than the environmental and social dimension. Distrust of consumers, lack of understanding and awareness of managers, and performance appraisal problems were found to be the most important barriers. Furthermore, informing the community by the media, entering the global market, exporting products, and producing sustainable products as a competitive advantage were identified to be the most important drivers. The study also shows that public awareness and demands can push the food supply chains toward sustainability goals with the cooperation of governments and suppliers.

The remainder is organized as follows: In Section 2, we review the literature regarding drivers and barriers of implementing sustainability in food supply chains. Section 3 presents materials including data collection as well as applied methods divided into Section 3.1 dealing with MCDM methods and Section 3.2 discussing aggregation methods. Section 4 highlights the results whereas Section 5 provides a discussion and conclusions including proposals for future work.

\section{Literature Review}

We review the literature regarding food supply chains including sustainability aspects analyzing drivers and barriers that serves as a basis for our own study. The literature is selected using an unstructured approach that is verified by a query in Web of Science (this encompasses a keyword search including the terms "food supply chains," "sustainability," "drivers and barriers" without any limitation of the publication time period or any other filter). We provide a narrative literature review resuming our findings by Tables 1 and 2. Moreover, we also consider neighboring areas of food supply chains, e.g., new energy technology products (see Malik et al. [16] and Bottani et al. [26]), CO2 emissions (see Hofmannet al. [17]), and ready-made garments (see Kumar et al. [15]).

We note that a great part of the related literature regarding drivers and barriers for sustainability considerations in (food) supply chains are literature reviews that distill drivers and barriers from the literature without further empirical evidence gathering and evaluation. We include some of these in our literature review but refrain from including all to not distort the picture toward drivers and barriers that are only mentioned more often due to studies referring to the same studies, but in different review works.

Salim et al. [27] study drivers and barriers in sustainable food retailing. They provide a literature review and semistructured interviews with retailers in Sweden identifying drivers, barriers, and concern factors in supply chain sustainability. These factors are based on the taxonomy of institutional factors defined by Massoud et al. [18] and are organized in four groups that form corporate supply chain responsibility encompassing resource factors that include tangible and intangible assets and derive from pressure of shareholders, suppliers, and investors, market factors including demand, competitions, and norms set by customers, competitors, industrial associations, and service provider pressure, regulatory factors, that derive from national and international governmental pressure, and social factors that comprise values and expectations of society, NGOs, media, academia, and court translated into pressure. Besides these factors, the authors also identify some other factors that trigger the adoption of sustainability initiatives for retails 
TABLE 1: Drivers and barriers individuated from literature review.

\begin{tabular}{|c|c|c|c|c|c|c|c|c|c|c|c|c|c|c|c|}
\hline Type & Issue & {$[12]$} & {$[14]$} & {$[15]$} & {$[16]$} & {$[17]$} & {$[18]$} & [19] & {$[20]$} & {$[21]$} & {$[22]$} & {$[23]$} & {$[24]$} & {$[57]$} & Count \\
\hline Driver & Enhancement of the company image & & $\mathrm{x}$ & & & & & & $\mathrm{x}$ & & & $\mathrm{x}$ & & $\mathrm{x}$ & 4 \\
\hline Driver & Environmental performance/benefits & & $\mathrm{x}$ & & & & & & & & & & $\mathrm{x}$ & $\mathrm{x}$ & 3 \\
\hline Driver & $\begin{array}{l}\text { Tax reliefs of certified companies/financial } \\
\text { benefits }\end{array}$ & & $\mathrm{x}$ & & & & & & & & & & $\mathrm{x}$ & & 2 \\
\hline Driver & Training and capacity building & & $\mathrm{x}$ & & & & & & & & & & & & 1 \\
\hline Driver & Collaboration with multitier suppliers & & & $\mathrm{x}$ & & & & & & & & & & & 1 \\
\hline Driver & Organizational benefits & & & & & & & & & & $\mathrm{x}$ & $\mathrm{x}$ & & $\mathrm{x}$ & 3 \\
\hline Driver & $\begin{array}{c}\text { Strategic support from industrial bodies, } \\
\text { nongovernmental organizations, and } \\
\text { developing agencies }\end{array}$ & & & $\mathrm{x}$ & & & & & & & & & & & 1 \\
\hline Driver & Economic benefits & & & & & & & & $\mathrm{x}$ & & $\mathrm{x}$ & $\mathrm{x}$ & $\mathrm{x}$ & $\mathrm{x}$ & 5 \\
\hline Driver & Good return on investment & & & & & & & & $\mathrm{x}$ & & & & & & 1 \\
\hline Driver & Business ethics & & & & & & & & $\mathrm{x}$ & & & & & $\mathrm{x}$ & 2 \\
\hline Barrier & $\begin{array}{l}\text { Lack/unawareness of governmental } \\
\text { regulations/support }\end{array}$ & & & & & $\mathrm{x}$ & $\mathrm{x}$ & & & & $\mathrm{x}$ & & & $\mathrm{x}$ & 4 \\
\hline Barrier & $\begin{array}{l}\text { High implementation costs/lack of financial } \\
\text { resources }\end{array}$ & & $\mathrm{x}$ & & & $\mathrm{x}$ & $\mathrm{x}$ & $\mathrm{x}$ & & & & $\mathrm{x}$ & $\mathrm{x}$ & $\mathrm{x}$ & 7 \\
\hline Barrier & $\begin{array}{c}\text { Lack of knowledge of the ISO } 14001 \text { standards/ } \\
\text { sustainability practice }\end{array}$ & & $\mathrm{x}$ & & & $\mathrm{x}$ & & & & & & & & & 2 \\
\hline Barrier & EMSs are not a legal requirement & & $\mathrm{x}$ & & & & & & & & $\mathrm{x}$ & & & & 2 \\
\hline Barrier & Benefits of EMSs are unclear & & $\mathrm{x}$ & & & & & & & & & & & & 1 \\
\hline Barrier & No customer demand & & $\mathrm{x}$ & & & & $\mathrm{x}$ & & & & $\mathrm{x}$ & & & $\mathrm{x}$ & 4 \\
\hline Barrier & Lack of top management commitment & & & $\mathrm{x}$ & $\mathrm{x}$ & & & & & & & & & $\mathrm{x}$ & 3 \\
\hline Barrier & Lack of appropriate IT systems/complexity & & & $\mathrm{x}$ & $\mathrm{x}$ & & & $\mathrm{x}$ & & & & & & & 3 \\
\hline Barrier & Lack of economic benefit & & & $\mathrm{x}$ & & & $\mathrm{x}$ & & & & & & & & 2 \\
\hline Barrier & Lack of trained (expert) staff & & & & $\mathrm{x}$ & & & & & & & & & & 1 \\
\hline Barrier & Firm size & & & & & $\mathrm{x}$ & & & & & & & & & 1 \\
\hline Barrier & Institutional/technological risks & & & & & & & & & & & & $\mathrm{x}$ & & \\
\hline \multirow[t]{3}{*}{ Barrier } & Inefficient bureaucracy & & & & & & $\mathrm{x}$ & & & & & & & & 1 \\
\hline & Drivers & 0 & 4 & 2 & 0 & 0 & 0 & 0 & 4 & 0 & 2 & 3 & 3 & 5 & \\
\hline & Barriers & 0 & 5 & 3 & 3 & 4 & 5 & 2 & 0 & 0 & 3 & 1 & 2 & 4 & \\
\hline
\end{tabular}

which are legitimacy, power, and urgency. They further influence decision-making and response to institutional pressure.

Einwiller et al. [19] investigate the adoption of environmental management systems (EMSs) including the application of the ISO 14001 standard for an emerging economy (Malaysia) and investigate drivers as well as barriers in food and beverage supply chains; see also Sugsaisakon and Kittipongvises [20] for a similar study on Lebanon. Einwiller et al. [19] survey 42 companies. Results show that there is a discrepancy in perception of small and medium-sized companies as well as large companies (see also [27] and the references therein) and between different product market groups; thus larger companies better understand the EMS concept. Main drivers of adopting EMSs are the enhancement of the company image and environmental performance. Main barriers are high implementation costs and lack of knowledge of the ISO 14001 standards. Besides, relative barriers include that EMSs are not a legal requirement, benefits of them are unclear, and there is no customer demand. Interestingly, among the least recognized barriers is that EMSs are not a CEO priority; thus the influence of motivation from upper management is not rated a barrier. This is in contrast to the findings of Hadikurniawati et al. [28] that reveal that one of three key operational barriers in integrating greening aspects into supply chains is the lack of internal top-level management commitment. Besides, the lack of integrated management information and traceability systems and uncertainty of economic benefits are also barriers. The most important incentives according to Einwiller et al. [19] are tax reliefs of certified companies as well as training and capacity building.

Hadikurniawati et al. [28] systematically analyze barriers to green supply chains and the implementation of associated practices in the peanut industry of western Africa. Their study bases on decision-making trial and evaluation laboratory (DEMATEL) technique involving four experts. Results show that effective green redesign of supply chains needs increased collaboration with multitier suppliers and strategic support from industrial bodies, nongovernmental organizations, and developing agencies. The authors use multicriteria decision-making methods to identify the most important barriers of green redesign from a focal company perspective. DEMATEL uses a structural modeling approach that identifies and groups key factors and visualizes causaleffect relationships in a diagram. Identified key operational barriers are the lack of internal top management commitment, lack of integrated management information and traceability systems, and uncertain economic benefits. Almutairi et al. [29] come to similar conclusions analyzing managerial perspectives of sustainability implementations in New Zealand by interviewing 29 senior managers from 23 
TABLE 2: Resume of related work and main characteristics of studies.

\begin{tabular}{|c|c|c|c|c|c|c|}
\hline Research & $\begin{array}{l}\text { Contributions of this article } \\
\text { compared to previous studies }\end{array}$ & $\begin{array}{l}\text { Method used in } \\
\text { research }\end{array}$ & Industry & $\begin{array}{l}\text { Sustainability aspects } \\
\text { in research }\end{array}$ & $\begin{array}{l}\text { Factors } \\
\text { examined in } \\
\text { research }\end{array}$ & $\begin{array}{l}\text { Case } \\
\text { study }\end{array}$ \\
\hline $\begin{array}{l}\text { Ghadge et al. } \\
(2020)\end{array}$ & Drivers case study & Fuzzy AHP & $\begin{array}{l}\text { Food } \\
\text { industry }\end{array}$ & $\begin{array}{c}\text { Economic } \\
\text { Environmental } \\
\text { Social }\end{array}$ & Barriers & $\mathrm{NO}$ \\
\hline $\begin{array}{l}\text { Bottani et al. } \\
(2019)\end{array}$ & $\begin{array}{l}\text { Drivers and barriers social } \\
\text { aspects } \\
\text { MCDM method }\end{array}$ & - & $\begin{array}{l}\text { Food } \\
\text { industry }\end{array}$ & $\begin{array}{c}\text { Economic } \\
\text { Environmental }\end{array}$ & - & YES \\
\hline Ali et al. (2019) & Drivers and barriers & Grey-DEMATEL & $\begin{array}{l}\text { Food } \\
\text { industry }\end{array}$ & $\begin{array}{l}\text { Economic } \\
\text { Environmental } \\
\text { Social }\end{array}$ & - & NO \\
\hline Kumar et al. (2019) & $\begin{array}{l}\text { Drivers and barriers } \\
\text { Environmental aspects }\end{array}$ & $\begin{array}{l}\text { Delphi method } \\
\text { and fuzzy AHP }\end{array}$ & $\begin{array}{l}\text { Fashion } \\
\text { industry }\end{array}$ & Social & Drivers & YES \\
\hline $\begin{array}{l}\text { Allaoui et al. } \\
\text { (2019) [25] }\end{array}$ & $\begin{array}{l}\text { Drivers and barriers } \\
\text { MCDM method }\end{array}$ & - & $\begin{array}{l}\text { Food } \\
\text { industry }\end{array}$ & $\begin{array}{c}\text { Economic, } \\
\text { environmental, social }\end{array}$ & - & $\mathrm{NO}$ \\
\hline $\begin{array}{l}\text { Sharma et al. } \\
(2018)\end{array}$ & $\begin{array}{l}\text { Drivers and barriers economic } \\
\text { and social aspects }\end{array}$ & FUZZY AHP & $\begin{array}{l}\text { Food } \\
\text { industry }\end{array}$ & Environmental & - & $\mathrm{NO}$ \\
\hline Dania et al. (2018) & $\begin{array}{c}\text { Drivers and barriers } \\
\text { MCDM }\end{array}$ & - & $\begin{array}{c}\text { Food } \\
\text { industry }\end{array}$ & $\begin{array}{l}\text { Economic, } \\
\text { environmental, social }\end{array}$ & - & YES \\
\hline Malik et al. (2019) & MCDM & - & Solar energy & $\begin{array}{l}\text { Economic, } \\
\text { environmental, social }\end{array}$ & $\begin{array}{l}\text { Drivers } \\
\text { Barriers }\end{array}$ & YES \\
\hline $\begin{array}{l}\text { Agyemang et al. } \\
(2018)\end{array}$ & $\begin{array}{l}\text { Drivers } \\
\text { Case study }\end{array}$ & Grey-DEMATEL & $\begin{array}{c}\text { Food } \\
\text { industry }\end{array}$ & $\begin{array}{l}\text { Economic, } \\
\text { environmental, social }\end{array}$ & Barriers & NO \\
\hline $\begin{array}{l}\text { Hussain et al. } \\
(2018)\end{array}$ & $\begin{array}{c}\text { Drivers } \\
\text { Economic and environmental } \\
\text { Aspects }\end{array}$ & AHP & Healthcare & Social & Barriers & YES \\
\hline Meijer et al. (2019) & MCDM & - & Solar energy & $\begin{array}{l}\text { Economic, } \\
\text { environmental, social }\end{array}$ & $\begin{array}{l}\text { Drivers } \\
\text { Barriers }\end{array}$ & YES \\
\hline $\begin{array}{l}\text { Chkanikova and } \\
\text { Mont. (2012) }\end{array}$ & $\begin{array}{c}\text { MCDM } \\
\text { Case study }\end{array}$ & - & $\begin{array}{l}\text { Food } \\
\text { industry }\end{array}$ & $\begin{array}{l}\text { Economic, } \\
\text { environmental, social }\end{array}$ & Drivers, barriers & NO \\
\hline Salim et al. (2018) & $\begin{array}{c}\text { Economic and social } \\
\text { Aspects } \\
\text { MCDM }\end{array}$ & - & $\begin{array}{c}\text { Food } \\
\text { industry }\end{array}$ & Environmental & Drivers, barriers & NO \\
\hline
\end{tabular}

companies where individuated drivers are customer expectation, top management commitment, moral and ethical values of managers, reputation management, and economic and operational benefits. Barriers include cost concerns, supplier and customer issues, and lack of regulations.

Allaoui et al. [30] develop a sustainable framework to reduce food waste using the Pareto method to identify risks. A total of 130 experts from food companies are interviewed. The authors use the grey DEMATEL technique to evaluate major risks in food supply chains. The five most important risks are identified as the lack of expert staff, poor leadership, information technology (IT) system failure, and poor customer relationship management. Several solutions are proposed to reduce risks.

Meijer et al. [31] examined the challenges of implementing sustainability in the food supply chain in the UK. Their study tries to identify the factors that hinder the implementation of sustainability in the cold food chain network by considering one of the cheese producers in the United Kingdom. Fuzzy hierarchical analysis and sensitivity analysis are used to identify and prioritize barriers to sustainability implementation. They divide the barriers into internal and external ones which are subsequently subcategorized. Their analysis shows that operational barriers pertaining to internal barriers were most significant. Thus, their results present key barriers such as initial investment costs, firm size, and unawareness of governmental regulations which are internal barriers. In fact, internal barriers seem to dominate the integration of sustainability practices such as lack of consensus regarding the sustainability concept. However, the misinterpretation of sustainability is subsumed under environmental barriers. However, the authors emphasize that sector-specific and country-specific supply chains differ and thus do implementation challenges. Chkanikova and Mont [32] explore drivers and barriers for the agrifood supply chain regarding the implementation of circular economy aspects highlighting that environmental, policy, and economic/financial benefits are top drivers whereas institutional, financial, and technological risks are the top barriers. The authors further state that there is a great need for internationally accepted standards and frameworks for circular economy as well as governmental interventions to push sustainability implementation.

Baghizadeh et al. [1] presented a mathematical model for a sustainable agrifood supply chain to minimize all costs and water and energy consumption. They suggested a G/M/S/M queuing system for first time in agrifood industry to improve transportation system and reduce waste. 
Agyemang et al. [33] explored the concept of sustainability to guide policies toward sustainable food systems. This study examines the literature and frameworks and uses stakeholder input to understand sustainability consisting of a comprehensive set of metrics for food system assessments. The authors provide a proof of concept of the operationalization of their approach and its metrics named the sustainability compass which aims at providing a comprehensive sustainability assessment framework that supports an integrated transparent policy dialog and insights on effects. However, they do not discuss drivers or barriers regarding the implementation of the sustainability framework.

Hofmann et al. [17] analyze two of the three sustainability dimensions, i.e., economic and environmental, for a cold chain logistics service company to investigate the total cost and $\mathrm{CO}_{2}$ emission. They propose an analytical model and show that the processes of product delivery and backroom storage require highest costs and emissions which is not surprising. Other processes identified by the study that require less of those are product collection and reverse logistics which is surprising as they require intensive product handling, dismantling, and transportation.

Malik et al. [16] studied drivers, barriers, and policies in sustainability development focusing on renewable energy within emerging countries, i.e., the Gulf Cooperation Council (GCC) member states. The picture is more similar for regenerative energy than for sustainability actions captured by, e.g., EMS. For instance, barriers to renewable energy deployment are high costs of electric generation from such sources, price distortions, or availability of conventional and cheaper energy sources as well as the lack of public awareness about the benefits of renewable energy. Besides, governments may also be reluctant to envision economic and environmental benefits. Barriers specific to GCC may be also inefficient bureaucracy and the lack of a combination of nonrenewable energy subsidies as well as the lack of support regarding renewable energy. The authors argue that, to overcome these barriers, there is a need for political intervention and economic support. Similarly, Bottani et al. [26] explore barriers and drivers in the commercialization of sustainable energy technologies by small and medium companies (SMEs) in the Netherlands. The latter are especially capable of commercializing sustainable technologies by developing innovative products as well as envisioning new organizational forms and business models. Although they are best suited to bring forward renewable energy products, there are drivers and barriers in the Netherlands that are interesting to study to bring forward the energy transition [26]. The authors list four barriers that seem to limit the commercialization of technology products for renewable energy, i.e., limited financial resources, technological complexity of solutions, significant market competition, and low legitimacy of solutions. On the other hand, main drivers are external financial investment, strong managerial and entrepreneurial expertise, early-stage prototyping, and piloting, as well as legitimizing solutions as qualitatively valuable.
Sajjad et al. [34] investigate key drivers and barriers for improving sustainability in supply chain management as a strategic goal regarding the Iranian oil and gas industry. They provide a comprehensive literature review to investigate drivers and barriers individuating 112 drivers and 41 barriers that are evaluated by 30 experts performing a Delphi threeround study. Results show the awareness that all three pillars (dimensions) of sustainability need to be regarded. The authors state that individual drivers are, a.o., customer satisfaction, importance of reducing environmental problems, financial resource allocation/incentives, as well as new warehousing, and control systems within the context of supply chain risk management. As seen already in other studies, barriers are high implementation costs of sustainability actions, banking problems, and/or the lack of financial resources.

Kumar et al. [15] investigate the drivers to implement sustainability aspect especially social responsibility methods in the ready-made garment (RMG) industry in the emerging country Bangladesh. Using the MCDM method Delphibased fuzzy AHP (F-AHP), the authors evaluated 10 industrial large scale RMG companies and employed 10 managers for the data evaluation. They reveal that the financial aspect is the main driver with the subcategories' sustainable economic benefits, maximization of the return of investment, business ethics, and enhanced reputation in global markets. Other investigated aspects are environmental-related drivers, societal drivers, and managementrelated drivers. Mithun Ali et al. [35] also apply AHP methods to evaluate barriers of the implementation of sustainability aspects in supply chains using a case of plastic manufacturing in India. They find out that barriers related to government support and policies are of highest importance.

As we can see from the literature review, main drivers for sustainability implementation in food supply chains are related to the company image and main barriers are the high investment costs, lack of appropriate IT tools, lack of economic benefits or customer demand for it, knowledge in concept and standards, and missing top management commitment. We are aware that the number of references used to generate the numbers in Table 1 is very small as the literature regarding drivers and barriers of implementing sustainability principles in the food supply chain is quite limited. However, already analyzing these studies, a trend becomes visible. Moreover, we highlight main characteristics of contributions in Table 2.

Table 2 presents characteristics of previous work that demonstrates the research gap and need for the contribution of this paper.

Sustainability in food supply chains is mostly studied with respect to the economic and environmental dimension (see [12, 16-18]) which includes either increasing profitability or reducing costs as well as reducing pollutants, e.g., $\mathrm{CO}_{2}$ emissions (see [26]). However, the long-term perspective of sustainability, such as caring for resources, so that they are available to future generations, e.g., reducing water consumption and reducing soil pollution (see also Mehmood et al. [36]), and the social dimension including goals like increasing social health or improving the unemployment rate have not been extensively and sufficiently 
addressed in available studies; see also the special issue paper of Hebinck et al. [37] that highlights the need for life cycle analysis (tools) especially regarding water and land use. Considering the main studies presented in the literature regarding drivers and barriers in food supply chains, we realize that our study is the most comprehensive approach including the analysis of drivers and barriers using MCDM by use of the case study.

\section{Materials and Methods}

We consider the above-mentioned concepts by focusing on rice as a product and its supply chain. Rice is a strategic product in Iran and has a critical role in the Iranian economy.

The study is based on surveyed literature as well as interviewing six experts of the field pertaining to the Ministry of Agriculture of Iran, JIHAD. These were interviewed examining the elements of a pairwise comparison. The list of elements is provided in Table 3. These elements have been derived by reviewing the literature, by observation, as well as expert interviews. The ranking methods AHP, TOPSIS-AHP, and COPRAS-AHP are used within the software Expert Choice ${ }^{\circledR}$ which is an AHP decision support software (see website: https://www.expertchoice.com/2021) and Microsoft Excel. The average weight, Borda, and Copeland methods are applied to integrate the ranks. After data collection and classification, we solve the model and interpret the results.

Our study is novel in comparison to work provided in the literature in the following manner:

(i) Use of MCDM techniques to identify and rank the drivers and barriers for a sustainable rice supply chain

(ii) Investigation of economic, social, and environmental dimensions of sustainability within the rice supply chain

(iii) Investigation of water consumption management, soil, and water pollution and its influence on community health

(iv) Ranking of individuated barriers and drivers using the AHP, TOPSIS-AHP, and COPRAS-AHP methods and use of the average weight, Borda, and Copeland methods to integrate the ranks

The barriers and drivers in Table 3 are explained in the following in more detail:

(1) Lack of understanding and awareness of managers (B1): given the commercialization of agriculture, increased demand for food worldwide, and increased concerns about food quality and security, the concepts of sustainability and supply chain management have become crucial. Sustainability management induces a new demand for managers [38]. Managers can help improve company performance and direct it toward sustainability [15]. Although sustainability in the food supply chain would raise the costs in organizations in the short run, it will enhance profitability in the long run. Apart from the economic perspective, sustainability brings social and environmental improvements, leading to economic growth and social health. Managers can bring benefits to both the organization and society by properly understanding sustainability. There may be misunderstanding and unawareness among managers and stakeholders of the definition and objectives of sustainability and their roles in the pursuit of sustainability. [7] Food supply chains can be directed toward sustainability by improving manager awareness.

(2) Performance appraisal problems (B2): to appraise the performance of a sustainable food supply chain, a powerful integrated information system is required that provides transparency. However, data collection is a time-consuming, costly, and expertdemanding process [28]. For instance, for the environmental perspective, the information system implements measures on parameters such as soil erosion, the use of harmful materials, energy consumption, and water use to render transparent detailed environmental information in order to start and support the sustainable supply chain and evaluate practices [1].

(3) Lack of expert staff (B3): inexperienced staff has a negative impact on the company and can contribute to waste production. Also, given the instructions in food production, inexpert staff may make mistakes and losses in products, reducing product quality and even endangering human health [30]. In contrast, expert staff can help minimize supply chain risks and food spoilage [19]. The lack of training in organizations on sustainability measures and the lack of workplace support have been identified as limitations for sustainability approaches [39]. Thus, the food supply chain can be directed toward sustainability by enhancing staff expertise.

(4) High cost of deployment (B4): the implementation of a sustainable supply chain requires high initial investments. Thus, organizations often lack sufficient financial resources [40]. Equipment, machinery, and integrated information systems are contributing to investment costs. However, in the long run, a sustainable food supply chain strategy can reduce costs [41].

(5) Lack of government oversight and control (B5): lack of government oversight to support sustainability has been identified as an important barrier [42], e.g., products that are not green and sustainable [27]. The government should intervene and control the market by detecting unsustainable products that have been labeled as sustainable and penalize the sellers. Also, the lack of government oversight and 
TABLE 3: Barriers and drivers of supply chain.

\begin{tabular}{|c|c|c|}
\hline Title & $\begin{array}{l}\text { Drivers/ } \\
\text { barriers }\end{array}$ & $\begin{array}{c}\text { References of drivers and } \\
\text { barriers }\end{array}$ \\
\hline Lack of understanding and awareness of managers about agrifood supply chain (AFSC) (B1) & Barriers & Literature review \\
\hline Performance appraisal problems in AFSC (B2) & Barriers & Literature review \\
\hline Lack of expert staff in sustainable AFSC (B3) & Barriers & $\begin{array}{l}\text { Expert interviews } \\
\text { Literature review }\end{array}$ \\
\hline High cost of deployment sustainable SC (B4) & Barriers & Literature review \\
\hline Lack of government oversight and control (B5) & Barriers & Literature review \\
\hline Consumer distrust of "green products" and "organic products" labels (B6) & Barriers & $\begin{array}{c}\text { Observation } \\
\text { Literature review }\end{array}$ \\
\hline Sustainable agrifood product cost (B7) & Barriers & Literature review \\
\hline Development of laws and policies for AFSC by the government (D1) & Drivers & Literature review \\
\hline Joint efforts and cooperation of suppliers for AFSC planning (D2) & Drivers & Literature review \\
\hline Producing sustainable products as a competitive advantage (D3) & Drivers & Literature review \\
\hline Encourage and support nongovernmental and eco-friendly organizations (D4) & Drivers & Literature review \\
\hline Informing the community by the media (D5) & Drivers & $\begin{array}{l}\text { Expert interviews } \\
\text { Literature review }\end{array}$ \\
\hline Entering the global market and exporting sustainable products (D6) & Drivers & $\begin{array}{c}\text { Observation } \\
\text { Expert interview }\end{array}$ \\
\hline
\end{tabular}

control setting off motivation and lacking pressure cause stagnancy in sustainable food supply chain implementation [38].

(6) Distrust of consumers (B6): the amount and additional eco-friendly labels on products in the market result in consumer confusion and makes it difficult to distinguish high-quality products [43]. This confusion leads to consumer distrust and induces a negative image of sustainable products.

(7) More expensive products (B7): the cost of sustainable products is higher than those of other products in the market since high-quality raw materials and international standards are applied [44]. Consumers seemingly choose affordability over quality. Furthermore, globalization and food supply chain complexity arise from searching for affordable food by consumers [27]. Some consumers believe that the quality of sustainable products is not high enough to explain higher costs in the supply chain [45]. This view stems from unawareness of sustainable food.

(8) Development of laws and policies by the government (D1): significantly elevated food standards, the rapid industrialization of agriculture-based products, and customer and government concerns about food security have brought further complexity to agricultural supply chain networks and agricultural products [46]. Such complex food supply chains have raised concerns in countries, such as fear of food security and unsustainable natural resource decline [47]. Governmental laws and policies play a key role in the implementation of sustainable supply chain practices [48]. Governments can contribute to sustainable food supply chain implementation by developing laws and policies.
(9) Joint efforts and cooperation of suppliers (D2): managers' cooperation and support for efficiently allocating resources and allowing for sharing strategic information for sustainability practices are crucial among supply chain members. Sustainability outcomes can be improved only by the complete participation of the partners. The supply chain partners need to help each other so that they could produce more sustainable outcomes and progress at the shared rate [49]. Cooperation provides an essential way of achieving a trade-off between all sustainable objectives by ignoring the individualistic and opportunistic behavior of supply chain stakeholders. For example, food waste has substantially increased due to complexities in food supply chain coordination [1]. Such problems could be tackled by cooperation and coordination in the food supply chain.

(10) Producing products as a competitive advantage (D3): sustainable food production is a competitive advantage and improves business productive performance and progress [50]. High-quality natural raw materials are employed to produce sustainable food under the relevant standards. Also, environmental and social aspects are considered in the supply chain process. This contributes to the health and growth of society and provides sustainable food with more benefits than other products in society [12].

(11) Encourage and support nongovernmental and ecofriendly organizations (D4): pressure and incentives of governmental and nongovernmental organizations are required to motivate sustainability in the agricultural sector [51]. NGOs and international development organizations play a key role in providing expertise to supply chain members for 
cooperation and implementing sustainability practices. Furthermore, such organizations and individuals could promote sustainable products and contribute to economic growth, society health, and environmental protection by consuming such products, increasing public awareness, and encouraging consumers to buy sustainable products.

(12) Informing the community by the media (D5): food security and safety are crucial in developing economies. Sustainability may help the health and safety of food. Public awareness of healthy and eco-friendly food induces concerns and motivates agricultural companies to focus on improving supply chain sustainability performance [52]. Companies attempting to implement sustainability respond to public pressure for launching sustainability activities [21]. Food and natural resource waste have declined in light of increased public awareness [5].

(13) Entering the global market and exporting products (D6): food security is crucial across the world and serves as a bridge between food and human health [50]. Since food is exported and imported in the world, food security has become a serious issue for both developed and developing countries. Sustainable food meets standards. Considering health and high quality, sustainable food can be introduced to the global market and raise export revenues.

The present study constructs the hierarchy with the objective, criteria, subcriteria, and alternatives to achieve the sustainable supply chain (see Figure 1).

The criteria involve the three main dimensions: economic, environmental, and social. The subcriteria involve the most important factors affecting the three sustainability dimensions. Through observations and expert interviews, a total of seven subcriteria are selected, including two economic subcriteria, three environmental subcriteria, and two social subcriteria.

3.1. MCDM Methods. We previously identify 13 alternatives including drivers and barriers (see Table 2). In this section, we shortly introduce the used methods for MCDM.

3.1.1. AHP. AHP is a structured technique for organizing and analyzing complex decisions using mathematics and psychological concepts. It quantifies weights of decision criteria by use of experts' experience to estimate the relative magnitude of factors through pairwise comparisons and includes several steps:

Step 1: establishing a hierarchy for the problem.

To establish a hierarchy, it is required to create hierarchical relationships of components at a given layer to components of higher and lower layer. In the simplest case, the first layer is the objective, the second layer involves criteria, and the third layer involves the alternatives. An AHP approach can involve also subcriteria. Step 2: constructing pairwise comparison matrices.

Once the hierarchy has been established, the decisionmaker is required to construct pairwise comparison matrices. This is performed for each level independently. In general, for $m$ alternatives and $n$ criteria, there is an $m \times m$ pairwise comparison matrix of alternatives and an $n \times n$ pairwise comparison matrix of criteria.

Step 3: calculating relative weights.

The decision factors are relatively weighted through a set of calculations. This prioritizes the decision factors based on the pairwise comparison matrix. The sum of the entities of each column is calculated. Then, each column entity is divided by the total value of the same column, obtaining the normalized matrix. Each row of the normalized matrix is averaged to represent the relative average weights of the decision factors.

Step 4: Ranking the alternatives, the relative weights are multiplied by the weights of higher alternatives to obtain the final weights of the alternatives.

Almost all the AHP calculations are performed by the judgment of the decision-maker in the form of the pairwise comparison matrix [53]. Comparison errors and inconsistencies would affect the calculation result. The inconsistency ratio measures the reliability of the priorities. For example, if alternative $\mathrm{A}$ is more important than alternative $\mathrm{B}$ and alternative $\mathrm{B}$ is more important than alternative $C$, alternative $A$ is expected to be much more important than alternative C. It is easy to compare two alternatives; however, such a comparison would not be easy for many alternatives. Thus, the inconsistency ratio is used to measure reliability. An inconsistency ratio below 0.1 represents reliable comparisons. Otherwise, comparisons should be reconsidered. The inconsistency ratio is calculated in some steps [22]:

(i) Calculate the weighted sum vector by multiplying the pairwise comparison matrix by the relative weight vector.

(ii) Divide the elements of the weight vector by the relative priorities to obtain the inconsistency vector.

(iii) Average the elements of the inconsistency vector $\lambda_{\max }$.

(iv) Calculate the inconsistency index as (1) where $n$ is the number of alternatives:

$$
I . I=\frac{\lambda_{\max }-n}{n-1} .
$$

(v) Calculate the inconsistency ratio as (2) where I.I.R is the inconsistency index of a random matrix:

$$
I . R=\frac{I . I}{I \cdot I \cdot R} \text {. }
$$




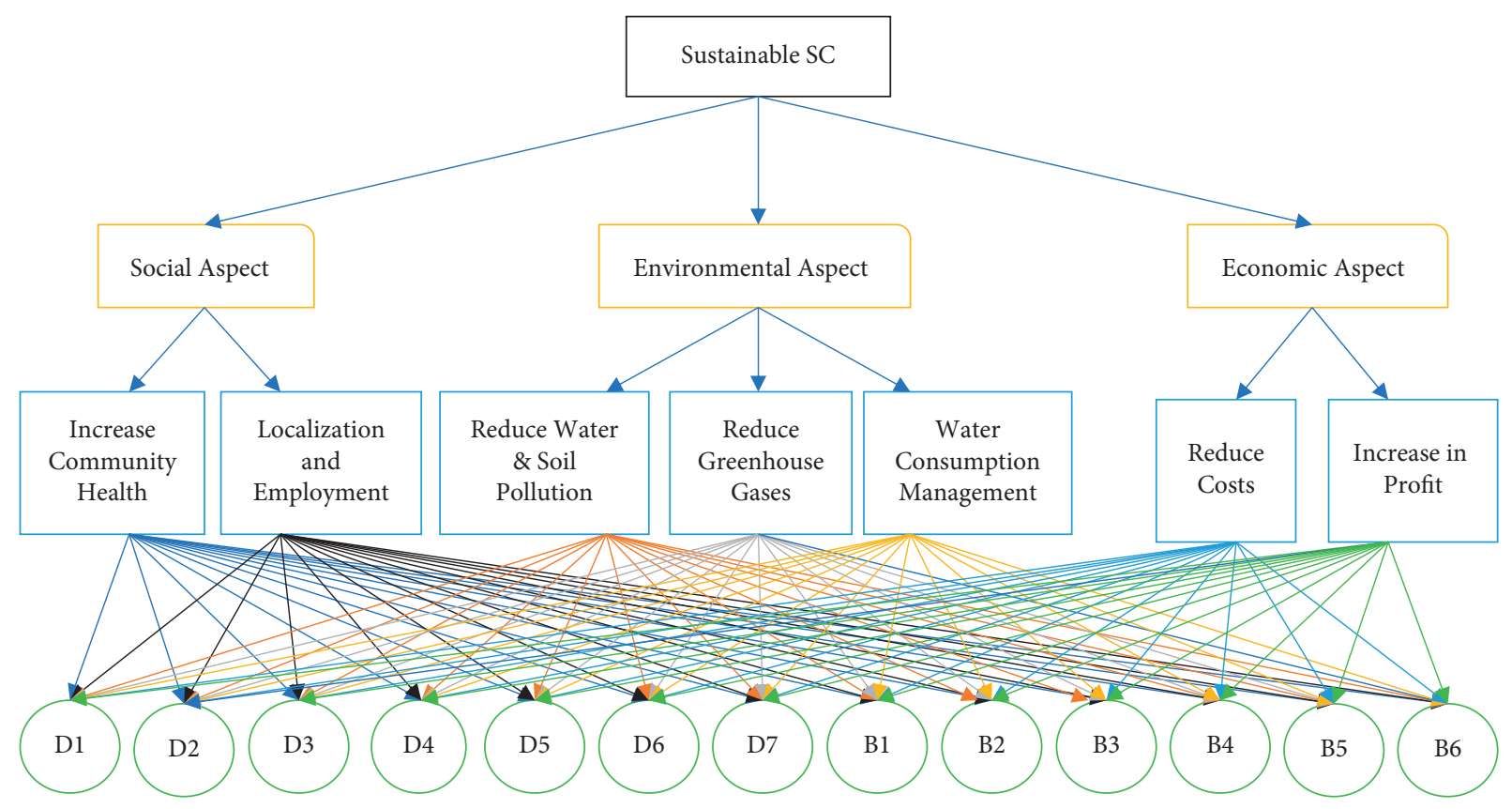

Figure 1: Decision-making hierarchy in presented rice supply chain.

3.1.2. TOPSIS-AHP. The technique for order of preferences by similarity to ideal solution (TOPSIS) is a MCDM of compensatory aggregation that compares a set of alternatives by identifying weights for each criterion, so that it normalizes scores for each criterion and calculates the geometric distance between each alternative and the ideal alternative where the latter is the best score in each criterion [51].

We apply the integrated TOPSIS-AHP method, because qualitative methods and quantitative methods with certain data have drawbacks in solving complex real-life problems with input and output uncertainties. To improve in efficiency and effectiveness, quantitative methods need to utilize descriptive data. The integration of AHP and TOPSIS is a solution in this respect [23]. Multiattribute decision-making (MADM) models are employed to select the optimal alternative based on the evaluation indexes. Hybrid procedures could maintain strengths and create multiple sources of knowledge and experience. To make more effective decisions, the AHP-TOPSIS integration is used to eliminate the drawbacks of individual AHP and TOPSIS. As an advantage, this integration produces a positive ideal and a negative ideal in the Euclidian space. This method transmits the alternatives to the Euclidian space, calculating the Euclidian distances of the alternatives from the positive and negative ideals. The alternatives with smaller distances from the positive ideal and larger distances from the negative ideal would have higher priority. This method is implemented in a number of steps [24]:

Steps 1 and 2: as with most multicriteria decisionmaking (MCDM) methods, the available data are transformed into a matrix with $m$ rows (alternatives) and $n$ columns (criteria). Index selection, hierarchy establishment, and criterion/subcriterion weighting are performed based on AHP. Also, the decision matrix is constructed, ranking the alternatives based on TOPSIS.

Step 3: the decision matrix is descaled using the vector method to eliminate the scales of different criteria and enable the comparisons of alternatives based on different criteria and the combination of the results:

$$
\begin{aligned}
r_{\mathrm{ij}} & =\frac{x_{\mathrm{ij}}}{\sqrt{\sum_{i}\left(x_{\mathrm{ij}}\right)^{2}}}, \\
i & =1, \ldots, m, \\
j & =1, \ldots, n .
\end{aligned}
$$

Step 4: the weight of each criterion is multiplied by the corresponding column in the descaled matrix to obtain matrix $V$ as

$$
v_{\mathrm{ij}}=w_{j} \times r_{\mathrm{ij}} .
$$

Let $w=\left(w_{1}, w_{2}, \ldots, w_{j}, \ldots, w_{n}\right)$ be the weight vector of the criteria. To obtain the weighted matrix, the weight vector is multiplied by the rows of the alternatives.

Step 5: the positive ideal $A^{+}$and negative ideal $A^{-}$are found as equations (5) and (6) where $J$ denotes positive criteria, while $J^{\prime}$ represents negative criteria. 


$$
\begin{aligned}
& A^{+}=\left\{\left(\max _{j} v_{\mathrm{ij}} \mid j \in J\right),\left(\min _{j} \mathrm{v}_{\mathrm{ij}} \mid j \in J^{\prime}\right), \forall_{i}=1,2, \ldots, m\right\}=\left\{v_{1}^{+}, v_{2}^{+}, \ldots, v_{n}^{+}\right\}, \\
& A^{-}=\left\{\left(\min _{j} v_{\mathrm{ij}} \mid j \in J\right),\left(\max _{j} \mathrm{v}_{\mathrm{ij}} \mid j \in J^{\prime}\right), \forall_{i}=1,2, \ldots, m\right\}=\left\{v_{1}^{-}, v_{2}^{-}, \ldots, v_{n}^{-}\right\} .
\end{aligned}
$$

Step 6: the distances of the alternatives from $A^{+}$and $A^{-}$ are calculated. Let $s_{i}^{+}$be the distance of alternative $i$ from $A^{+}$and $s_{i}^{-}$be the distance of alternative $i$ from $A^{-}$. Then, for $i=1,2, \ldots, m, s_{i}^{+}$and $s_{i}^{-}$are obtained as

$$
\begin{gathered}
s_{i}^{+}=\sqrt{\sum_{j=1}^{n}\left(v_{i j}-v_{j}^{+}\right)^{2}}, \\
s_{i}^{-}=\sqrt{\sum_{j=1}^{n}\left(v_{i j}-v_{j}^{-}\right)^{2}} .
\end{gathered}
$$

Step 7: the alternatives are prioritized based on either closeness to the positive ideal or distantness from the negative ideal.

3.1.3. COPRAS-AHP. Complex proportional assessment (COPRAS) is a decision-making method for prioritizing or ranking alternatives [52]. It exploits alternative weights. COPRAS was developed to determine priorities and effectiveness of alternatives. It was employed to assess maximization and minimization criteria. The effects of the minimization and maximization criteria on the results are evaluated independently. COPRAS-AHP is applied using the subsequently described steps [54]:

Steps 1 and 2: index selection, hierarchy establishment, and criterion/subcriterion weighting are carried out using AHP. Then, a decision matrix is constructed. Ranking is performed by COPRAS.

Step 3: the decision matrix is normalized as equation (8), where $x_{-} i j$ denotes the criteria.

$$
R=\left[r_{\mathrm{ij}}\right]_{m \times n}=\frac{x_{\mathrm{ij}}}{\sum_{i=1}^{m} x_{\mathrm{ij}}} .
$$

Step 4: the normalized decision matrix is weighted as equation (9), where $w_{j}$ is the weight of criterion $j$.

$$
D=\left[y_{\mathrm{ij}}\right]_{m \times n}=r_{\mathrm{ij}} \times w_{j} \text {. }
$$

Step 5: positive and negative criteria are determined. Then, it is required to determine the final values of the positive and negative criteria as

$$
\begin{aligned}
& s_{+i}=\sum_{j=1}^{n} y_{+i j}, \\
& s_{-i}=\sum_{j=1}^{n} y_{-i j} .
\end{aligned}
$$

Step 6: the criteria are subjected to pairwise ranking based on the positive and negative criteria as the following equation:

$$
Q_{i}=s_{+i}+\frac{s-\min \sum_{i=1}^{m} s_{-i}}{s_{-i} \sum_{i=1}^{m}\left(s-\min / s_{-i}\right)} .
$$

Step 7: the best alternatives are identified. A rise (reduction) in the rank of an alternative raises (reduces) its importance. The best alternatives are denoted by the importance index $U_{i}\left(U_{i}=100 \%\right)$ which is calculated by equation (13). The importance of each criterion varies from $0 \%$ to $100 \%$, where $Q_{i}$ is the importance index, while $Q_{\max }$ is the maximum importance of the ideal alternative.

$$
U_{i}=\left[\frac{Q_{i}}{Q_{\max }}\right] \times 100 \% .
$$

3.2. Aggregation Methods. Since employing multiple MCDM techniques can cause inconsistent results, these must be combined using a group of strategies named rank aggregation. The methods used in this study for this purpose are Rank Averaging, the Borda technique, and Copeland technique [41].

The Rank Averaging method calculates the average rank of each alternative based on the ranks in MCDM methods. Prioritization is performed based on the alternatives. The alternatives with lower arithmetic means would have higher priorities [24].

Within the Borda method, a pairwise comparison matrix is built for decision-making. An entity in the matrix is set to 1 when the corresponding alternative has more wins than losses over the other alternatives. Likewise, an entity is set to 0 when its losses and wins are equal in number. A value of 1 implies the superiority of the row over the column, whereas a value of 0 indicates the preference of the column over the row. The sum of the entities in a row represents the number of each alternative's wins over the other alternatives, and the alternatives are prioritized based on their numbers of wins. There is a total of $m(m-1) / 2$ pairwise comparisons, in which $m$ denotes the number of alternatives. The prioritization criterion is the number of each alternative's wins [24].

The Copeland method is a modified variant of the Borda method, in which not only the number of wins (the sum of entities in each row) but also the number of losses (the sum of entities in each column) are employed in prioritization. Prioritization is performed based on the difference between the number of wins and the number of losses [55]. 


\section{Results}

In this section, we present and discuss the results of our case study.

4.1. MCDM Method Results. As described in detail in the previous section, three MCDM approaches, AHP, TOPSISAHP, and COPRAS-AHP, have been used in this study. The results of these methods are presented in the following.

4.1.1. AHP Results. Once the hierarchy of the study is constructed, a pairwise comparison matrix is built to compare the criteria, subcriteria, and alternatives based on the objective (i.e., sustainability). After building the pairwise comparison matrix and developing the questionnaire, industrial experts responded to the questionnaire. As sustainability has economic, environmental, and social dimensions, the economic questions are responded by managers, experienced and educated agricultures, Ministry of Agriculture JIHAD managers in the rice department, and experts. Also, the environmental questions were responded by Ministry of Agricultural JIHAD experts in the fertilizer and pesticide department, Ministry of Agriculture JIHAD managers in the environmental and food health department, and environmental activists. Finally, the social questions are responded by students at the Kharazmi University, Iran, Ministry of Agriculture managers, and environmentalists. Once the questionnaires had been responded to, the geometric mean of the collected data is calculated. Table 4 compares the criteria.

The pairwise comparison matrix is introduced to Expert Choice ${ }^{\circledR}$ to weight and rank the criteria and subcriteria, as reported in Table 5. As can be seen from the table presented, the largest weight of the sustainability subset, which consists of three parts, is related to the economic dimension. In second and third place are environmental and social dimensions, respectively.

Sales enhancement and cost reduction were selected as economic subcriteria based on the expert responses. Sustainable food has higher quality and nutritional value than other products as they are produced under standards. This enhances the sales of sustainable food, increasing profits and improving sustainability from an economic perspective. As with increased sales, cost reduction could increase profits in the food supply chain. The costs of the food supply chain could be significantly reduced by reengineering production, machinery and equipment repair and maintenance, employing experts and thus experienced staff, reducing transportation in different supply chain stages, selecting the most suitable suppliers, exploiting technology, using an integrated information system, returning reusable raw materials back to the cycle, and utilizing waste as the inputs of other supply chains. Table 6 shows the weights of the economic subcriteria.

Concerning the environmental dimension of sustainability, air pollution by greenhouse gas emission when farmers burn their farmlands after the first round of cultivation for the second cultivation round, water
TABLE 4: Matrix of pairwise comparisons of criteria.

\begin{tabular}{lccc}
\hline & Economic & Environmental & Social \\
\hline Economic & 1 & 2 & 2.81 \\
Environmental & & 1 & 1.07 \\
Social & & & 1 \\
\hline
\end{tabular}

TABLE 5: Subcriteria weights.

\begin{tabular}{lccc}
\hline Subcriteria & Social & Environmental & Economic \\
\hline Subcriteria weight & 0.211 & 0.247 & 0.542 \\
\hline
\end{tabular}

TABLE 6: Weights of the economic subcriteria.

\begin{tabular}{lcc}
\hline Subcriteria & Reduce costs & Increase profit \\
\hline Subcriteria weight & 0.5 & 0.5 \\
\hline
\end{tabular}

contamination due to chemical fertilizers and pesticides penetrating groundwater resources, soil decline due to the lack of soil reinforcement and the transformation of grasslands into farmlands, excessive animal grazing, the lack of drinking water resource management in agriculture and water waste, the degradation of the ecosystem in contact with fertilizers and pesticides, the lack of experts and implementation of unscientific agriculture, and the nonuse of organic fertilizers are among those factors that lead to an unsustainable rice supply chain. Table 7 provides the weights of the environmental subcriteria.

It is necessary to strongly consider food quality and nutritional values in the food supply chain and avoid environmental damage when using resources in the supply chain, so that the environment could be preserved for future generations. Table 8 reports the weights of the social subcriteria.

The final ranks of the alternatives are calculated and presented in Table 9 where the first seven rows are the barriers, while the remaining six rows represent the drivers.

According to the presented table, the most influential elements in the proposed supply chain are (1) lack of understanding and awareness of managers, (2) lack of expert staff, and (3) performance appraisal problems, which are all subject to the proposed barriers.

As mentioned earlier, the pairwise comparison matrix is valid when it contains rational items and is consistent. The data are reliable and can be used in decision-making when the inconsistency rate is below 0.1. An inconsistency rate above 0.1 represents unreliable data, and the data must be revised. The inconsistency rate is calculated to be 0.06 in Expert Choice ${ }^{\circledR}$, indicating that the matrix is valid, as shown in Figure 2.

Figure 3 shows dynamic sensitivity analysis results. The weights of the criteria are indicated on the left side, while the final weights of the alternatives are shown on the right side. This figure shows that (1) lack of understanding and awareness of managers is the most important factor for sustainability and next important barrier is lack of experts in the industry. 
TABLE 7: Weights of the environmental subcriteria.

\begin{tabular}{lccc}
\hline Subcriteria & Reduce water and soil pollution & Reduce greenhouse gases & Water consumption management \\
\hline Subcriteria weight & 0.389 & 0.138 & 0.474 \\
\hline
\end{tabular}

TABLe 8: Weights of the social subcriteria.

\begin{tabular}{lcc}
\hline Subcriteria & Increase community health & Localization and employment \\
\hline Subcriteria weight & 0.533 & 0.467 \\
\hline
\end{tabular}

TABLE 9: Ranking of drivers and barriers based on the AHP method.

\begin{tabular}{|c|c|c|c|}
\hline Factors & Alternative & Weight & Rank \\
\hline \multirow{7}{*}{ Barriers } & B1 & 0.151 & 1 \\
\hline & B2 & 0.101 & 3 \\
\hline & B3 & 0.132 & 2 \\
\hline & B4 & 0.086 & 4 \\
\hline & B5 & 0.082 & 6 \\
\hline & B6 & 0.056 & 9 \\
\hline & B7 & 0.072 & 7 \\
\hline \multirow{6}{*}{ Drivers } & D1 & 0.086 & 4 \\
\hline & D2 & 0.057 & 8 \\
\hline & D3 & 0.038 & 13 \\
\hline & D4 & 0.045 & 11 \\
\hline & D5 & 0.052 & 10 \\
\hline & D6 & 0.042 & 12 \\
\hline
\end{tabular}

Synthesis with respect to:

sustainability

Overall Inconsisteny $=/ 06$

1 lack of understanding and awareness of managers

2 performance appraisal problems

3 lack of expert staff

4 high cost of deployment

5 lack of government oversight and control

6 distrust of consumers

7 being more expensive

8 development of laws and policies by the government

9 joint efforts and cooperation of suppliers

10 produce products as a competitive advantage

11 encourage and support non-governmental organizations a...

12 informing the community by the media

13 entering the global market and exporting products

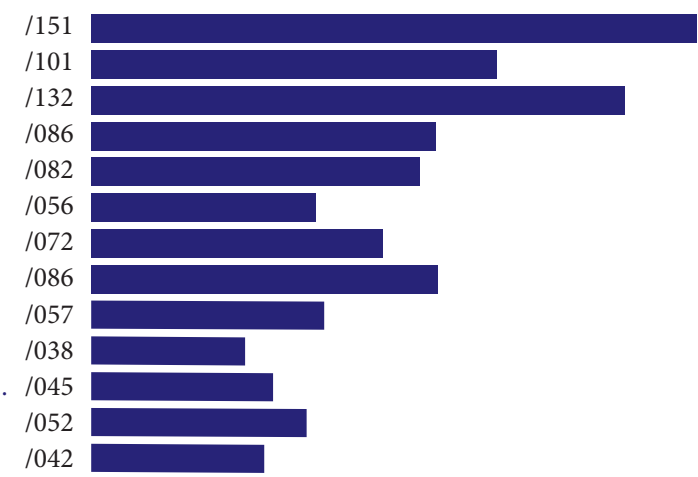

Figure 2: Inconsistency rate.

The dynamic sensitivity analysis is a method that is used to study time-varying sensitivities in dynamic systems. It is based on the effects of the criteria and is depicted as a linear diagram, where the horizontal axis represents the criteria encompassing those of the economic, environmental, and social sustainability dimensions, while the weights of the criteria are illustrated in the form of bar charts.

As can be seen in Figure 4, the economic criterion had the largest weight, followed by environmental and social criteria, showing desirable values on the vertical axis. In the economic criterion, the lack of understanding and awareness of managers, the lack of expert staff, performance appraisal problems, high cost of deployment, and sustainable products being more expensive had the highest utility. In the environmental criterion, the lack of understanding and awareness of managers, lack of expert staff, performance appraisal problems, lack of government oversight and control, and development of laws and policies by the government had highest ranks. In the social criterion, lack of understanding and awareness of managers, lack of expert staff, development of laws and policies by the government, high cost of deployment, and performance appraisal problems had the highest utility. Finally, lack of understanding and awareness of managers, lack of expert staff, performance appraisal 

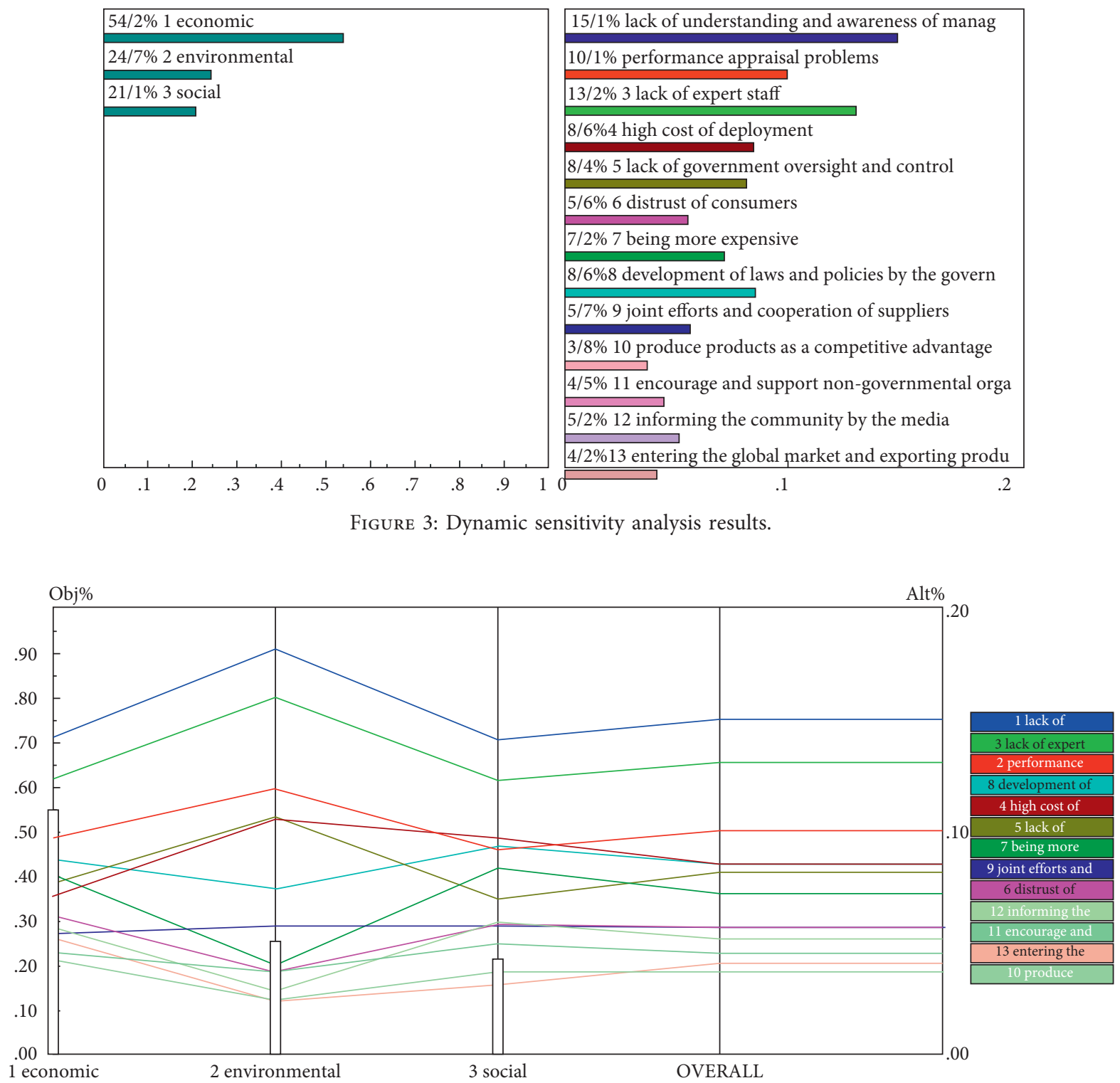

Figure 4: Effectiveness of the criteria and sensitive analysis.

problems, high cost of deployment, and development of laws and policies by the government were identified as the five most important items. Figure 4 illustrates the effectiveness of the criteria.

This analysis is represented in the form of diagrams. A sloped line is used for each criterion versus each alternative, in which the slope represents the rise or decline in the utility of the alternative as the weight of the corresponding criterion rises. The weight of the criterion is shown by a vertical line, the intersection of which with the sloped line of each alternative represents the utility of the alternative. Figures 5-7 depict the results of the economic, environmental, and social criteria by red lines.

Figures 8-10 have two dimensions, and each line represents a criterion. The alternatives are depicted as dots, and each alternative's dominance of the other alternatives can be observed. Figure 8 compares the economic criterion on the horizontal axis versus the environmental criterion on the vertical axis, Figure 9 compares the economic criterion on the horizontal axis versus the social criterion on the vertical axis, and Figure 10 compares the environmental criterion on the horizontal axis versus the social criterion on the vertical axis.

4.1.2. TOPSIS-AHP Results. The hybrid TOPSIS-AHP technique is employed to construct a hierarchy of the criteria and subcriteria and weight them using Expert Choice ${ }^{\circledR}$ and rank the criteria and subcriteria using TOPSIS. The decision matrix scores the alternatives based on the criteria by experts. The geometric mean of the expert responses is calculated, as shown in Table 10. Table 11 presents decision matrix that is normalized by vector unscaling. Moreover, the subcriteria are weighted using AHP, as represented in Table 12. Positive and negative criteria, positive and negative ideal point, distances of the points from the positive and negative ideals and final rank are presented in Tables 13-16. 


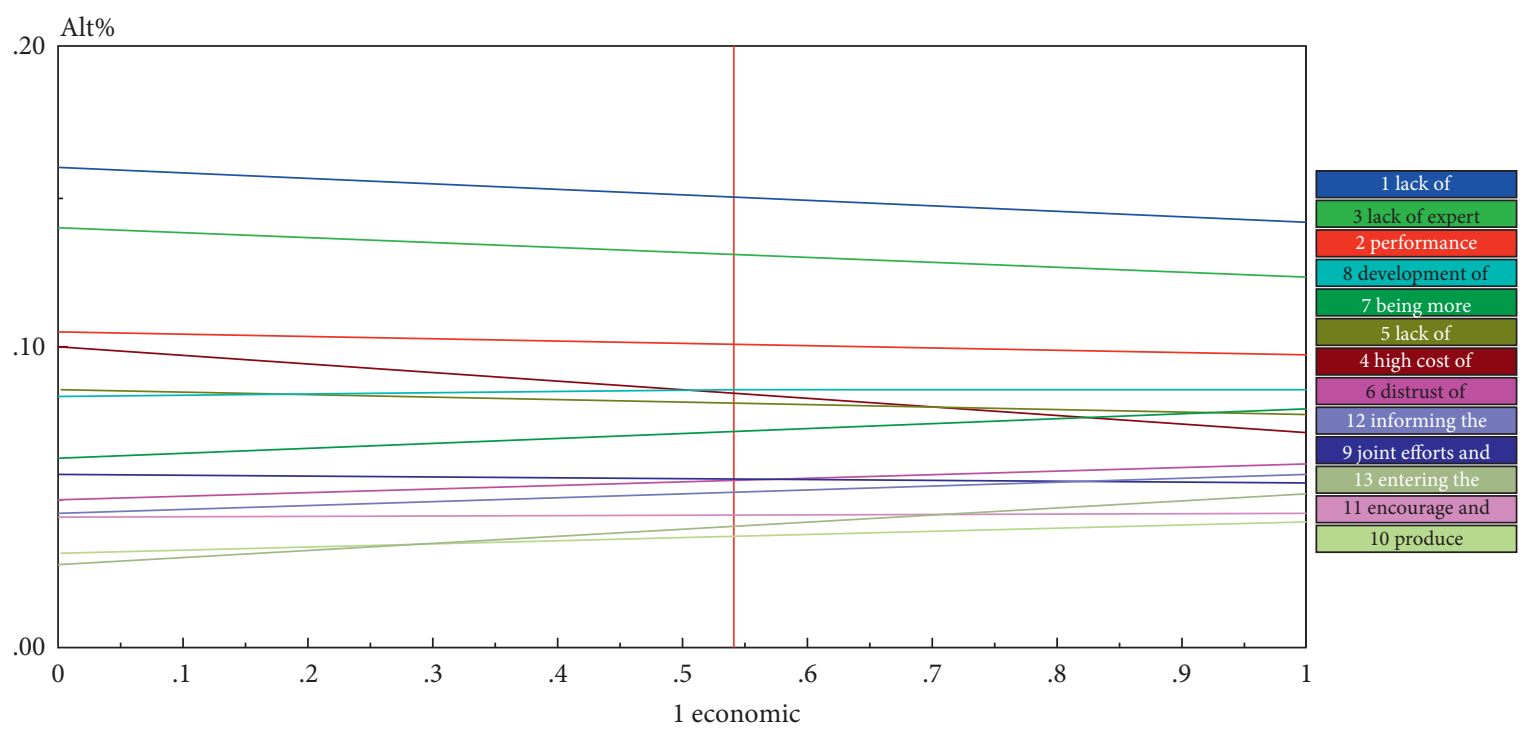

Figure 5: Desirability of alternatives for economic criteria.

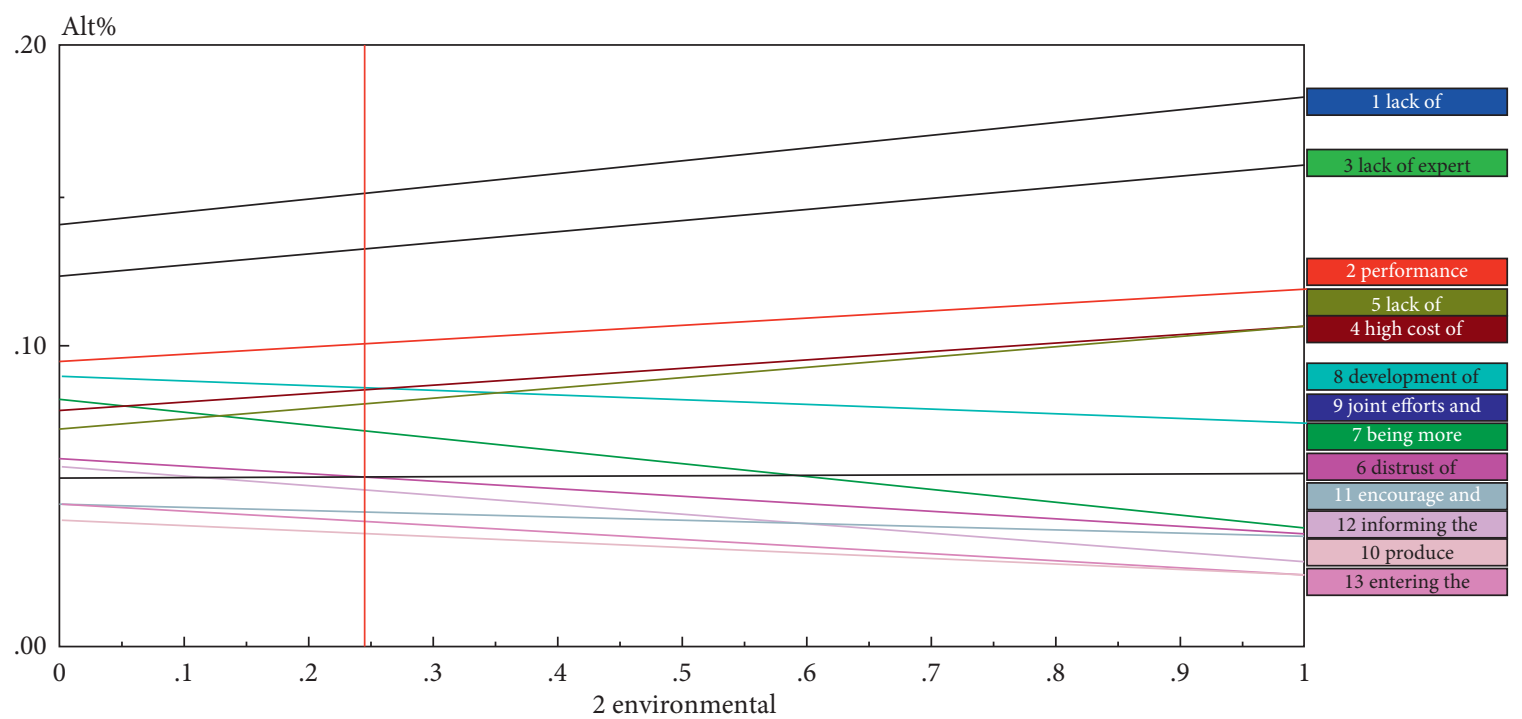

FiguRE 6: Desirability of alternatives for environmental criteria.

According to the calculations performed by AHP method and its results, it can be said that the following three elements have the greatest effect on the supply chain sustainability:

(1) Informing the community by the media

(2) Entering the global market and exporting products

(3) Producing products as a competitive advantage

4.1.3. COPRAS-AHP Results. In this research, the hybrid COPRAS-AHP method is employed to weight the criteria and subcriteria using AHP and perform ranking by COPRAS. The decision matrix scores the alternatives based on the criteria by expert responses. The geometric mean of the expert responses is calculated, as represented in Table 17.
The decision matrix is normalized. Table 17 represents the first normal form of the decision matrix along with positive and negative criteria. The subcriteria are weighted using AHP. The decision matrix is multiplied by the weights which is presented in Table 18. Table 19 reports the final negative and positive values. Tables 20 and 21 show comparative ranking of the alternatives and final ranking.

Based on COPRAS-AHP results in Table 20, it can be deduced that the most important factors involved in supply chain stability are presented as follows: Distrust of consumers, entering the global market and exporting products, and, finally, producing products as a competitive advantage.

The ranks of the alternatives in the AHP, TOPSIS-AHP, and COPRAS-AHP techniques are presented in Figure 11. This figure shows the ranking of each element in each of the three techniques used. As can be seen, the importance and 


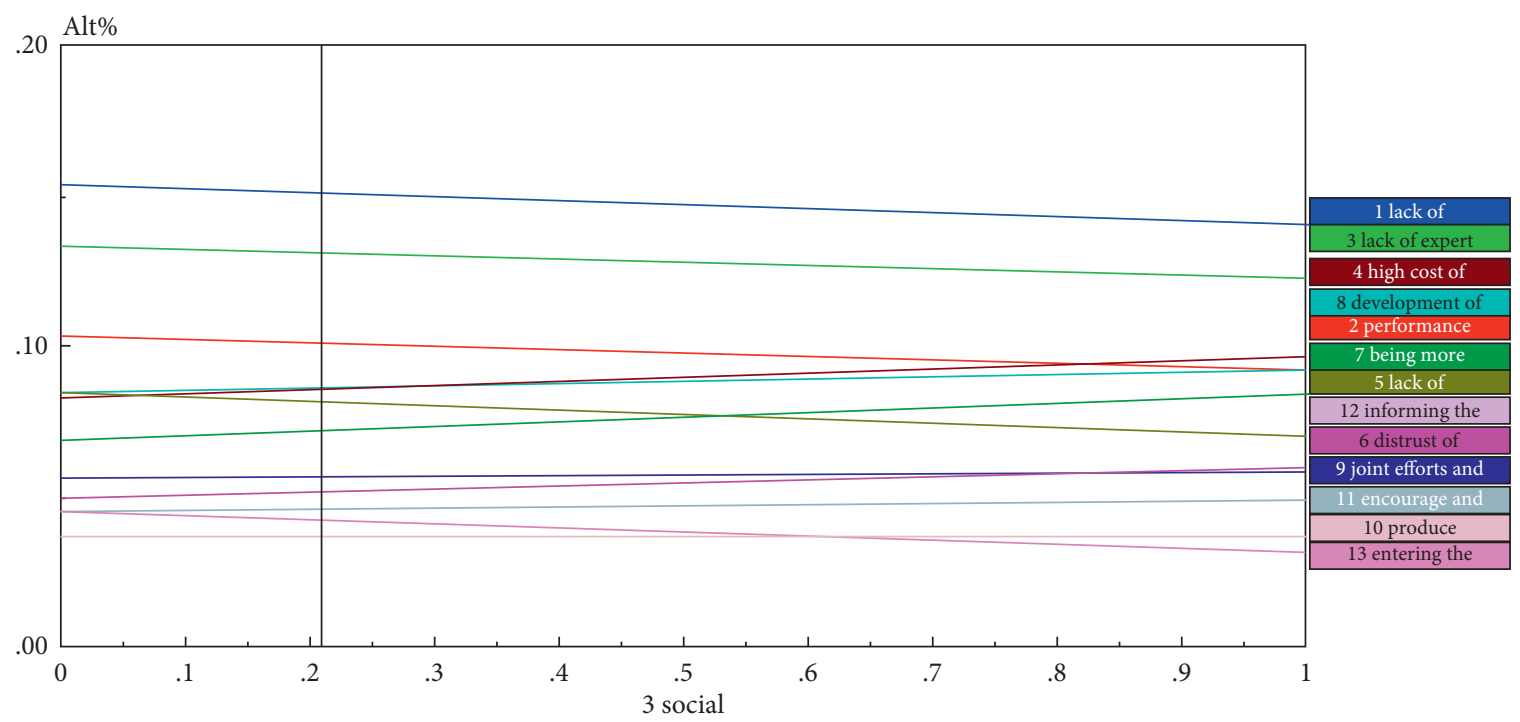

Figure 7: Desirability of alternatives for economic criteria.

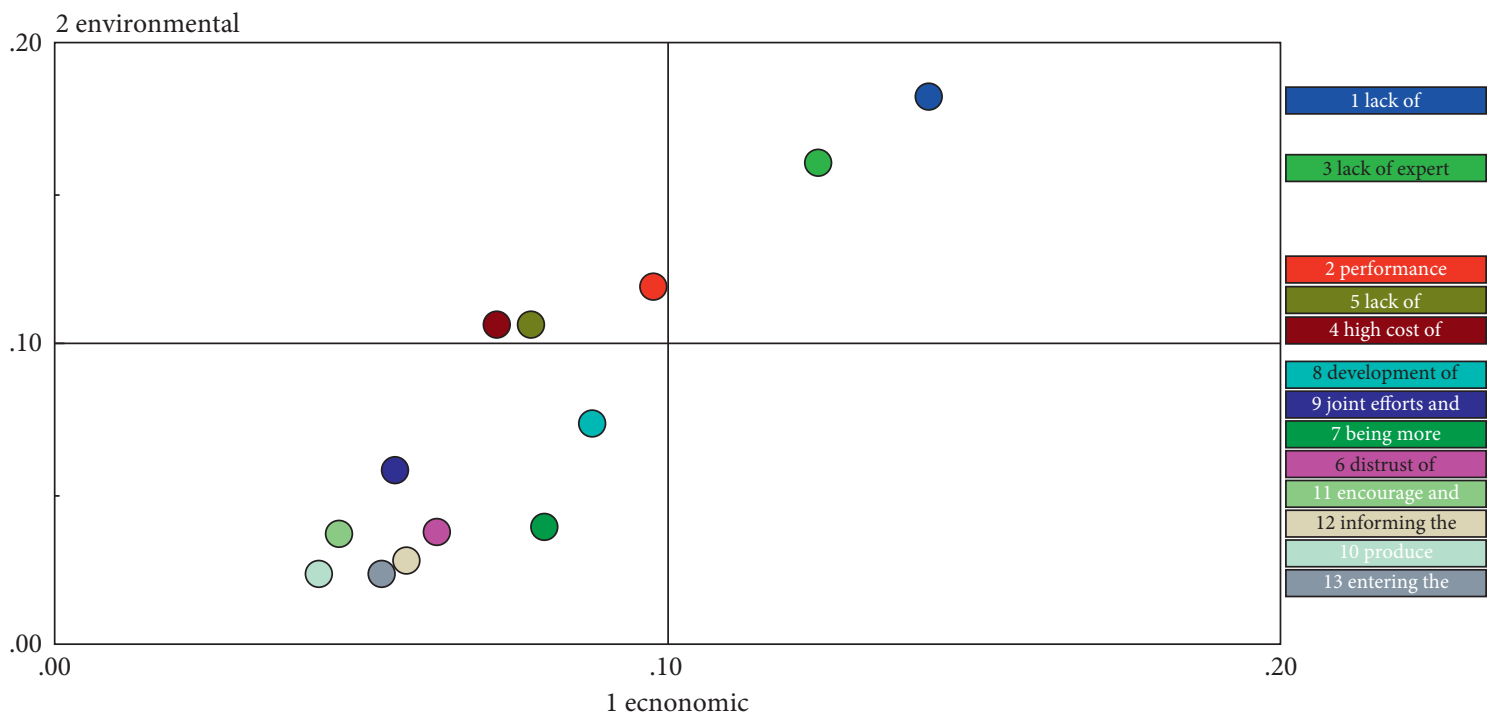

FIGURE 8: Comparing the economic criterion versus environmental criterion.

impact of each barrier and driver on supply chain sustainability are different in all of techniques. For this reason, to obtain a final answer, we must use the techniques of combining approaches to achieve the most important elements affecting sustainability.

4.2. Aggregation Methods. Because the use of multiple MCDM methods may lead to conflicting results, they should be combined using a group of methods called rank aggregation methods. The methods used in this research for this purpose are the Rank Averaging (RA), Borda and Copeland methods.
4.2.1. Rank Averaging (RA). The average rank of the alternatives is calculated by summing up the ranks of each alternative in different techniques and dividing the total value by the number of techniques, as reported in Table 22 .

The most important elements are lack of understanding and awareness of managers, Distrust of consumers, and informing the community by the media.

4.2.2. Borda Method. The Borda method is implemented in Excel and results are reported in Table 23.

In this approach distrust of consumers is the most effective factor and the second place is assigned to informing the community by the media. 


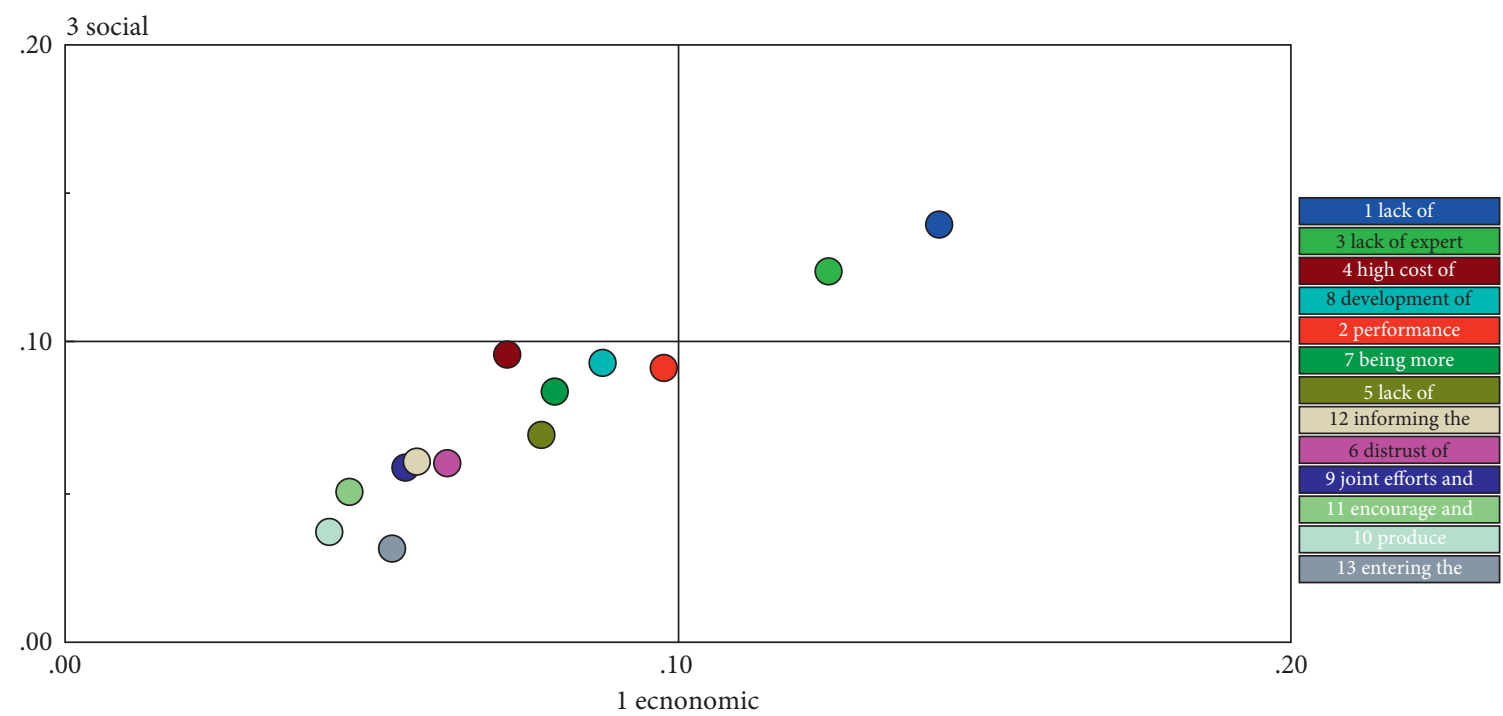

Figure 9: Comparing the economic criterion versus social criterion.

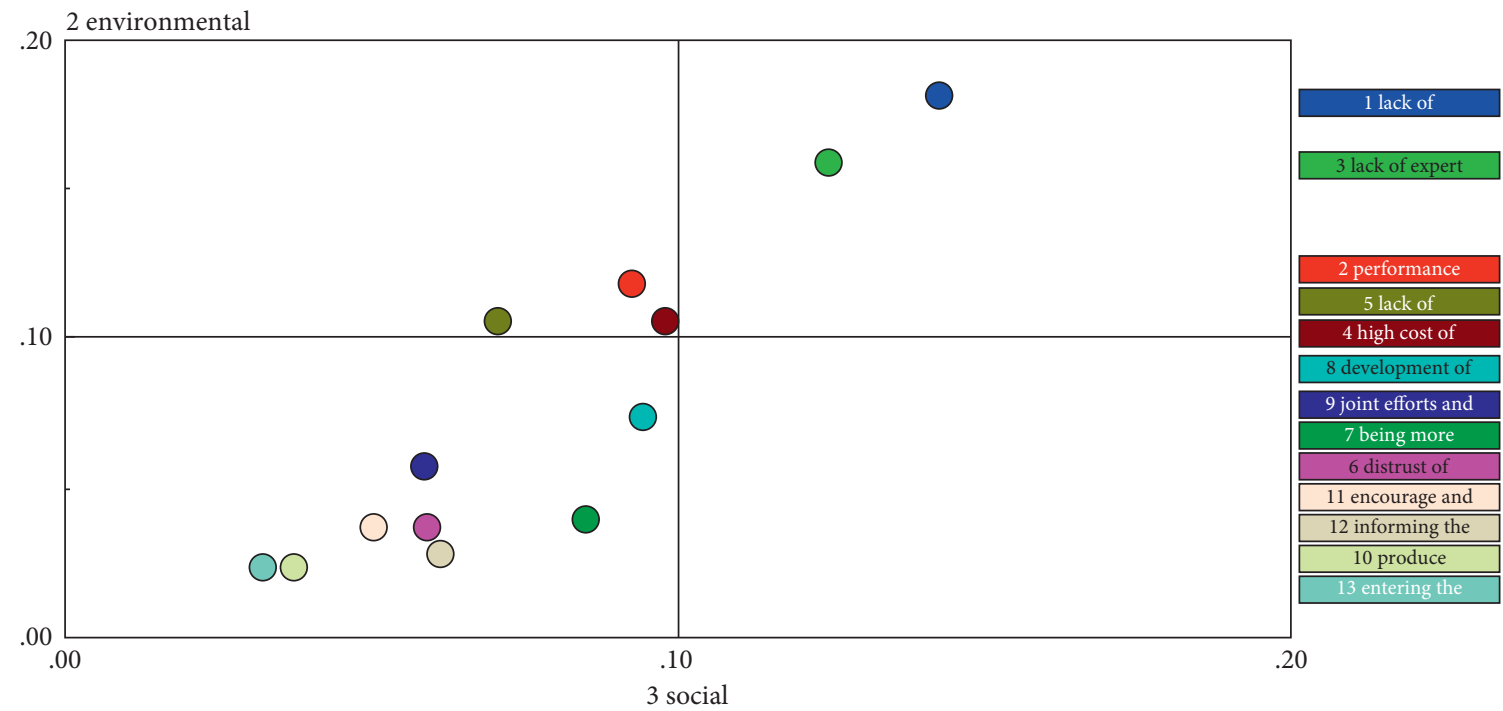

FIGURE 10: Comparing the environmental criterion versus social criterion.

TABLE 10: Normalized decision matrix based on the AHP method.

\begin{tabular}{|c|c|c|c|c|c|c|c|}
\hline & \multicolumn{2}{|c|}{ Economic } & \multicolumn{3}{|c|}{ Environmental } & \multicolumn{2}{|c|}{ Social } \\
\hline & $\begin{array}{c}\text { Increase } \\
\text { profit }\end{array}$ & $\begin{array}{c}\text { Reduce } \\
\text { costs }\end{array}$ & $\begin{array}{c}\text { Water consumption } \\
\text { management }\end{array}$ & $\begin{array}{c}\text { Decrease } \\
\text { greenhouse gases }\end{array}$ & $\begin{array}{l}\text { Reduce water and } \\
\text { soil pollution }\end{array}$ & $\begin{array}{c}\text { Localization and } \\
\text { employment }\end{array}$ & $\begin{array}{c}\text { Increase } \\
\text { community health }\end{array}$ \\
\hline B1 & 0.25224 & 0.25992 & 0.34242 & 0.35979 & 0.32328 & 0.31523 & 0.26523 \\
\hline B2 & 0.21346 & 0.25709 & 0.31157 & 0.23634 & 0.28352 & 0.26356 & 0.26554 \\
\hline B3 & 0.18688 & 0.36799 & 0.27962 & 0.29703 & 0.29382 & 0.25083 & 0.21129 \\
\hline B4 & 0.18688 & 0.24173 & 0.21444 & 0.22532 & 0.25414 & 0.23913 & 0.15835 \\
\hline B5 & 0.21346 & 0.25400 & 0.30395 & 0.32288 & 0.29739 & 0.21998 & 0.27854 \\
\hline B6 & 0.21606 & 0.14956 & 0.13600 & 0.16294 & 0.15553 & 0.14592 & 0.18734 \\
\hline B7 & 0.22391 & 0.30050 & 0.14624 & 0.13941 & 0.13958 & 0.22510 & 0.18962 \\
\hline D1 & 0.20598 & 0.33892 & 0.32682 & 0.31937 & 0.31977 & 0.32707 & 0.29589 \\
\hline D2 & 0.33291 & 0.35509 & 0.28977 & 0.24834 & 0.27029 & 0.37250 & 0.25315 \\
\hline D3 & 0.32124 & 0.22795 & 0.25413 & 0.24834 & 0.23705 & 0.30418 & 0.32556 \\
\hline D4 & 0.32087 & 0.24510 & 0.32682 & 0.33098 & 0.31977 & 0.26646 & 0.32518 \\
\hline D5 & 0.37504 & 0.25709 & 0.30395 & 0.32288 & 0.28352 & 0.28650 & 0.39389 \\
\hline D6 & 0.42250 & 0.27611 & 0.27325 & 0.29380 & 0.34342 & 0.31523 & 0.34965 \\
\hline
\end{tabular}


TABLe 11: Decision matrix based on expert responses.

\begin{tabular}{|c|c|c|c|c|c|c|c|}
\hline & \multicolumn{2}{|c|}{ Economic } & \multicolumn{3}{|c|}{ Environmental } & \multicolumn{2}{|c|}{ Social } \\
\hline & $\begin{array}{l}\text { Increase } \\
\text { profit }\end{array}$ & $\begin{array}{l}\text { Reduce } \\
\text { costs }\end{array}$ & $\begin{array}{c}\text { Water consumption } \\
\text { management }\end{array}$ & $\begin{array}{c}\text { Decrease } \\
\text { greenhouse gases }\end{array}$ & $\begin{array}{l}\text { Reduce water and } \\
\text { soil pollution }\end{array}$ & $\begin{array}{c}\text { Localization and } \\
\text { employment }\end{array}$ & $\begin{array}{c}\text { Increase } \\
\text { community health }\end{array}$ \\
\hline B1 & 4.94 & 4.76 & 6.83 & 7.00 & 6.59 & 5.51 & 5.31 \\
\hline B2 & 4.18 & 4.71 & 6.21 & 4.60 & 5.78 & 4.61 & 5.32 \\
\hline B3 & 3.66 & 6.75 & 5.58 & 5.78 & 5.99 & 4.38 & 4.23 \\
\hline B4 & 3.66 & 4.43 & 4.28 & 4.38 & 5.18 & 4.18 & 3.17 \\
\hline B5 & 4.18 & 4.66 & 6.06 & 6.28 & 6.06 & 3.84 & 5.58 \\
\hline B6 & 4.23 & 2.74 & 2.71 & 3.17 & 3.17 & 2.55 & 3.75 \\
\hline B7 & 4.38 & 5.51 & 2.92 & 2.71 & 2.84 & 3.93 & 3.80 \\
\hline D1 & 4.03 & 6.21 & 6.52 & 6.21 & 6.52 & 5.72 & 5.92 \\
\hline D2 & 6.52 & 6.51 & 5.78 & 4.83 & 5.51 & 6.51 & 5.07 \\
\hline D3 & 6.29 & 4.18 & 5.07 & 4.83 & 4.83 & 5.32 & 6.52 \\
\hline D4 & 6.28 & 4.49 & 6.52 & 6.44 & 6.52 & 4.66 & 6.51 \\
\hline D5 & 7.34 & 4.71 & 6.06 & 6.28 & 5.78 & 5.01 & 7.88 \\
\hline D6 & 8.27 & 5.06 & 5.45 & 5.72 & 7.00 & 5.51 & 7.00 \\
\hline
\end{tabular}

TABLE 12: Subcriteria weight.

\begin{tabular}{lccccccc}
\hline $\begin{array}{l}\text { Increase } \\
\text { profit }\end{array}$ & $\begin{array}{c}\text { Reduce } \\
\text { costs }\end{array}$ & $\begin{array}{c}\text { Water consumption } \\
\text { management }\end{array}$ & $\begin{array}{c}\text { Decrease } \\
\text { greenhouse gases }\end{array}$ & $\begin{array}{c}\text { Reduce water } \\
\text { and soil pollution }\end{array}$ & $\begin{array}{c}\text { Localization and } \\
\text { employment }\end{array}$ & $\begin{array}{c}\text { Increase } \\
\text { community } \\
\text { health }\end{array}$ & $\begin{array}{c}\text { Subcriteria } \\
\text { emplont }\end{array}$ \\
\hline 0.27 & 0.27 & 0.12 & 0.03 & 0.10 & 0.10 & 0.11 & Weight \\
\hline
\end{tabular}

Table 13: Positive and negative criteria.

\begin{tabular}{|c|c|c|c|c|c|c|c|}
\hline & $\begin{array}{l}\text { Subcriteria } \\
\text { (positive) } \\
\text { Increase } \\
\text { profit }\end{array}$ & $\begin{array}{c}\text { Subcriterion } \\
\text { (negative) }\end{array}$ & $\begin{array}{l}\text { Subcriterion } \\
\text { (positive) } \\
\text { Water } \\
\text { consumption } \\
\text { management }\end{array}$ & $\begin{array}{l}\text { Subcriterion } \\
\text { (negative) } \\
\text { Decrease } \\
\text { greenhouse } \\
\text { gases }\end{array}$ & $\begin{array}{c}\begin{array}{c}\text { Subcriterion } \\
\text { (negative) }\end{array} \\
\text { Reduce water and } \\
\text { soil pollution }\end{array}$ & $\begin{array}{l}\text { Subcriterion } \\
\text { (positive) } \\
\text { Localization and } \\
\text { employment }\end{array}$ & $\begin{array}{c}\text { Subcriterion } \\
\text { (positive) } \\
\text { Increase } \\
\text { community } \\
\text { health }\end{array}$ \\
\hline B1 & 0.06836 & 0.07044 & 0.04006 & 0.01223 & 0.03103 & 0.03121 & 0.02971 \\
\hline B2 & 0.05785 & 0.06967 & 0.03645 & 0.00804 & 0.02722 & 0.02609 & 0.02974 \\
\hline B3 & 0.05065 & 0.09972 & 0.03271 & 0.01010 & 0.02821 & 0.02483 & 0.02366 \\
\hline B4 & 0.05065 & 0.06551 & 0.02509 & 0.00766 & 0.02440 & 0.02367 & 0.01774 \\
\hline B5 & 0.05785 & 0.06883 & 0.03556 & 0.01098 & 0.02855 & 0.02178 & 0.03120 \\
\hline B6 & 0.05855 & 0.04053 & 0.01591 & 0.00554 & 0.01493 & 0.01445 & 0.02098 \\
\hline B7 & 0.06068 & 0.08143 & 0.01711 & 0.00474 & 0.01340 & 0.02228 & 0.02124 \\
\hline D1 & 0.05582 & 0.09185 & 0.03824 & 0.01086 & 0.03070 & 0.03238 & 0.03314 \\
\hline D2 & 0.09022 & 0.09623 & 0.03390 & 0.00844 & 0.02595 & 0.03688 & 0.02835 \\
\hline D3 & 0.08706 & 0.06177 & 0.02973 & 0.00844 & 0.02276 & 0.03011 & 0.03646 \\
\hline D4 & 0.08696 & 0.06642 & 0.03824 & 0.01125 & 0.03070 & 0.02638 & 0.03642 \\
\hline D5 & 0.10164 & 0.06967 & 0.03556 & 0.01098 & 0.02722 & 0.02836 & 0.04412 \\
\hline D6 & 0.11450 & 0.07483 & 0.03197 & 0.00999 & 0.03297 & 0.03121 & 0.03916 \\
\hline
\end{tabular}

TABle 14: Positive and negative ideal points.

\begin{tabular}{cccccccc}
\hline $\begin{array}{c}\text { Increase } \\
\text { profit }\end{array}$ & $\begin{array}{c}\text { Reduce } \\
\text { costs }\end{array}$ & $\begin{array}{c}\text { Water consumption } \\
\text { management }\end{array}$ & $\begin{array}{c}\text { Decrease } \\
\text { greenhouse gases }\end{array}$ & $\begin{array}{c}\text { Reduce water and } \\
\text { soil pollution }\end{array}$ & $\begin{array}{c}\text { Localization and } \\
\text { employment }\end{array}$ & $\begin{array}{c}\text { Increase } \\
\text { community health }\end{array}$ \\
\hline$A^{+}$ & 0.11450 & 0.04053 & 0.04006 & 0.00474 & 0.01340 & 0.03688 & 0.04412 \\
$A^{-}$ & 0.05065 & 0.09972 & 0.01591 & 0.01223 & 0.03297 & 0.01445 & 0.01774 \\
\hline
\end{tabular}

TABLE 15: Distances of the points from the positive and negative ideals.

\begin{tabular}{lcr}
\hline Alternative & $D j+$ & $D j-$ \\
\hline B1 & 0.06025 & 0.04672 \\
B2 & 0.06779 & 0.04132 \\
B3 & 0.09190 & 0.02127 \\
\hline
\end{tabular}


TABle 15: Continued.

\begin{tabular}{lcc}
\hline Alternative & $D j+$ & $D j-$ \\
\hline B4 & 0.07697 & 0.03787 \\
B5 & 0.06851 & 0.04060 \\
B6 & 0.06895 & 0.06283 \\
B7 & 0.07637 & 0.03081 \\
D1 & 0.08097 & 0.03396 \\
D2 & 0.06441 & 0.05081 \\
D3 & 0.03894 & 0.06060 \\
D4 & 0.04408 & 0.05851 \\
D5 & 0.03657 & 0.06938 \\
D6 & 0.04134 & 0.07550 \\
\hline
\end{tabular}

TABLE 16: Final ranking based on the AHP method.

\begin{tabular}{lccc}
\hline & $D_{j}$ & Normalized $D_{j}$ & Rank \\
\hline B1 & 0.43676 & 0.07681 & 7 \\
B2 & 0.37870 & 0.06660 & 8 \\
B3 & 0.18797 & 0.03306 & 13 \\
B4 & 0.32978 & 0.05800 & 10 \\
B5 & 0.37210 & 0.06544 & 9 \\
B6 & 0.47675 & 0.08385 & 5 \\
B7 & 0.28748 & 0.05056 & 12 \\
D1 & 0.29547 & 0.05196 & 11 \\
D2 & 0.44096 & 0.07755 & 6 \\
D3 & 0.60877 & 0.10706 & 3 \\
D4 & 0.57033 & 0.10030 & 1 \\
D5 & 0.65486 & 0.11517 & 2 \\
D6 & 0.64619 & 0.11364 & 2 \\
\hline
\end{tabular}

TABLE 17: Normalized decision-making matrix with positive and negative criteria.

\begin{tabular}{|c|c|c|c|c|c|c|c|}
\hline \multirow[b]{2}{*}{ Alternative } & \multicolumn{4}{|c|}{ Positive criteria } & \multicolumn{3}{|c|}{ Negative criteria } \\
\hline & $\begin{array}{l}\text { Increase } \\
\text { profit }\end{array}$ & $\begin{array}{l}\text { Reduce } \\
\text { costs }\end{array}$ & $\begin{array}{c}\text { Water consumption } \\
\text { management }\end{array}$ & $\begin{array}{c}\text { Decrease } \\
\text { greenhouse gases }\end{array}$ & $\begin{array}{l}\text { Reduce water and } \\
\text { soil pollution }\end{array}$ & $\begin{array}{l}\text { Localization and } \\
\text { employment }\end{array}$ & $\begin{array}{c}\text { Increase } \\
\text { community } \\
\text { health }\end{array}$ \\
\hline B1 & 0.07266 & 0.09758 & 0.08926 & 0.07580 & 0.07361 & 0.10258 & 0.09181 \\
\hline B2 & 0.06149 & 0.08879 & 0.07463 & 0.07589 & 0.07281 & 0.06738 & 0.08052 \\
\hline B3 & $0.053 \mathrm{~T} 83$ & 0.07969 & 0.07102 & 0.06038 & 0.10422 & 0.08469 & 0.08345 \\
\hline B4 & 0.05383 & 0.06111 & 0.06771 & 0.04525 & 0.06846 & 0.06424 & 0.07218 \\
\hline B5 & 0.06149 & 0.08662 & 0.06229 & 0.07960 & 0.07193 & 0.09206 & 0.08446 \\
\hline B6 & 0.06224 & 0.03876 & 0.04132 & 0.05354 & 0.04236 & 0.04646 & 0.04417 \\
\hline B7 & 0.06450 & 0.04167 & 0.06374 & 0.05419 & 0.08510 & 0.03975 & 0.03964 \\
\hline D1 & 0.05934 & 0.09314 & 0.09261 & 0.08456 & 0.09598 & 0.09106 & 0.09082 \\
\hline D2 & 0.09590 & 0.08258 & 0.10547 & 0.07235 & 0.10056 & 0.07080 & 0.07676 \\
\hline D3 & 0.09254 & 0.07242 & 0.08613 & 0.09304 & 0.06456 & 0.07080 & 0.06732 \\
\hline D4 & 0.09243 & 0.09314 & 0.07545 & 0.09293 & 0.06941 & 0.09436 & 0.09082 \\
\hline D5 & 0.10804 & 0.08662 & 0.08112 & 0.11257 & 0.07281 & 0.09206 & 0.08052 \\
\hline D6 & 0.12171 & 0.07787 & 0.08926 & 0.09992 & 0.07820 & 0.08376 & 0.09753 \\
\hline
\end{tabular}

Table 18: Weighted matrix.

\begin{tabular}{lccccccc}
\hline & $\begin{array}{c}\text { Increase } \\
\text { profit }\end{array}$ & $\begin{array}{c}\text { Reduce } \\
\text { costs }\end{array}$ & $\begin{array}{c}\text { Water consumption } \\
\text { management }\end{array}$ & $\begin{array}{c}\text { Decrease } \\
\text { greenhouse gases }\end{array}$ & $\begin{array}{c}\text { Reduce water and } \\
\text { soil pollution }\end{array}$ & $\begin{array}{c}\text { Localization and } \\
\text { employment }\end{array}$ & $\begin{array}{c}\text { Increase } \\
\text { community health }\end{array}$ \\
\hline B1 & 0.01969 & 0.01142 & 0.00880 & 0.00852 & 0.01995 & 0.00350 & 0.00882 \\
B2 & 0.01666 & 0.01040 & 0.00735 & 0.00853 & 0.01973 & 0.00230 & 0.00774 \\
B3 & 0.01459 & 0.00933 & 0.00700 & 0.00679 & 0.02824 & 0.00289 & 0.00802 \\
B4 & 0.01459 & 0.00715 & 0.00667 & 0.00509 & 0.01855 & 0.00219 & 0.00693 \\
B5 & 0.01666 & 0.01014 & 0.00614 & 0.00895 & 0.01949 & 0.00314 & 0.00812 \\
B6 & 0.01687 & 0.00454 & 0.00407 & 0.00602 & 0.01148 & 0.00158 & 0.00424 \\
B7 & 0.01748 & 0.00488 & 0.00628 & 0.00609 & 0.02306 & 0.00135 & 0.00381 \\
\hline
\end{tabular}


TABLE 18: Continued.

\begin{tabular}{lccccccc}
\hline & $\begin{array}{c}\text { Increase } \\
\text { profit }\end{array}$ & $\begin{array}{c}\text { Reduce } \\
\text { costs }\end{array}$ & $\begin{array}{c}\text { Water consumption } \\
\text { management }\end{array}$ & $\begin{array}{c}\text { Decrease } \\
\text { greenhouse gases }\end{array}$ & $\begin{array}{c}\text { Reduce water and } \\
\text { soil pollution }\end{array}$ & $\begin{array}{c}\text { Localization and } \\
\text { employment }\end{array}$ & $\begin{array}{c}\text { Increase } \\
\text { community health }\end{array}$ \\
\hline D1 & 0.01608 & 0.01090 & 0.00913 & 0.00951 & 0.02601 & 0.00310 & 0.00873 \\
D2 & 0.02599 & 0.00967 & 0.01039 & 0.00814 & 0.02725 & 0.00241 & 0.00738 \\
D3 & 0.02508 & 0.00848 & 0.00849 & 0.01046 & 0.01749 & 0.00241 & 0.00647 \\
D4 & 0.02505 & 0.01090 & 0.00743 & 0.01045 & 0.01881 & 0.00322 & 0.00873 \\
D5 & 0.02928 & 0.01014 & 0.00799 & 0.01266 & 0.01973 & 0.00314 & 0.00774 \\
D6 & 0.03298 & 0.00912 & 0.00880 & 0.01124 & 0.02119 & 0.00286 & 0.00937 \\
\hline
\end{tabular}

TABle 19: Negative and positive value of alternatives.

\begin{tabular}{lcc}
\hline Alternatives & $S_{+i}$ & $S_{-i}$ \\
\hline B1 & 0.03991 & 0.04079 \\
B2 & 0.03441 & 0.03830 \\
B3 & 0.03092 & 0.04594 \\
B4 & 0.02842 & 0.03277 \\
B5 & 0.03294 & 0.03970 \\
B6 & 0.02548 & 0.02333 \\
B7 & 0.02864 & 0.03432 \\
D1 & 0.03611 & 0.04735 \\
D2 & 0.04605 & 0.04518 \\
D3 & 0.04204 & 0.03684 \\
D4 & 0.04339 & 0.04120 \\
D5 & 0.04741 & 0.04327 \\
D6 & 0.05089 & 0.04465 \\
\hline
\end{tabular}

TABLe 20: Final ranks of alternatives.

\begin{tabular}{lcc}
\hline Alternative importance & $U_{i}$ & Rank \\
\hline B1 & 85 & 7 \\
B2 & 82 & 9 \\
B3 & 71 & 13 \\
B4 & 83 & 8 \\
B5 & 79 & 11 \\
B6 & 100 & 1 \\
B7 & 81 & 10 \\
D1 & 75 & 12 \\
D2 & 88 & 6 \\
D3 & 92 & 3 \\
D4 & 89 & 5 \\
D5 & 91 & 4 \\
D6 & 94 & 2 \\
\hline
\end{tabular}

TABLE 21: Comparative ranking of the alternatives.

\begin{tabular}{lc}
\hline Alternatives & $Q_{i}$ \\
\hline B1 & 0.07692 \\
B2 & 0.07382 \\
B3 & 0.06378 \\
B4 & 0.07448 \\
B5 & 0.07096 \\
B6 & 0.09018 \\
B7 & 0.07262 \\
D1 & 0.06799 \\
D2 & 0.07946 \\
D3 & 0.08302 \\
D4 & 0.08002 \\
D5 & 0.08230 \\
D6 & 0.08470 \\
\hline
\end{tabular}

4.2.3. Copeland. The Copeland method is an extension to the Borda method. The difference is the number of wins minus the number of losses, as shown in Table 24. Table 24 represents the integrated ranks of the average weight, Borda, and Copeland methods. Copeland results are the same as Borda results. Distrust of consumers is the most effective factor, and the second place is assigned to informing the community by the media.

As we have seen, the analysis of the three used techniques is necessary to provide valuable decision support. According to the results obtained from the AHP, TOPSIS-AHP, and COPRASAHP methods, the most effective factor in increasing and improving the sustainability of the supply chain in this study is distrust of consumers. In the second place, informing the community by the media has a significant impact on all three dimensions of sustainability. 


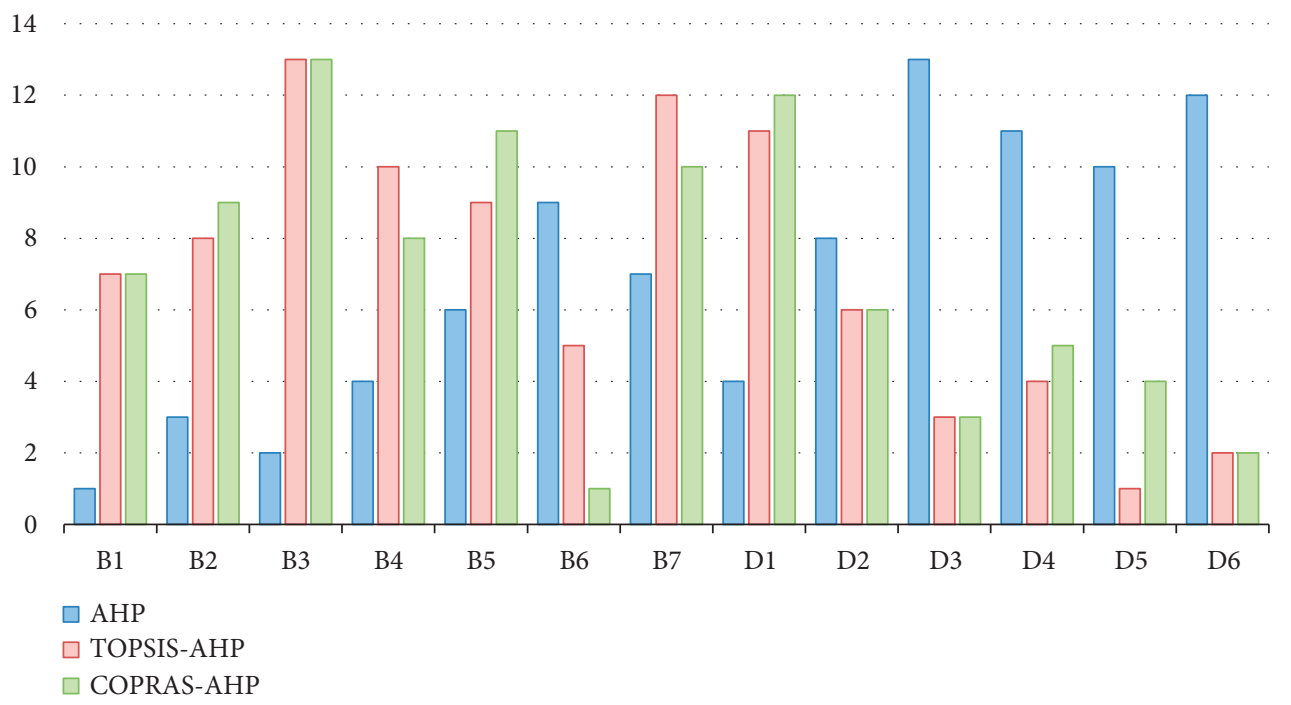

FIGURE 11: Alternatives ranks in AHP, TOPSIS-AHP, and COPRAS-AHP method.

TABLE 22: Final score of alternatives based on rank averaging.

\begin{tabular}{lcccc}
\hline & AHP method & TOPSIS-AHP method & COPRAS-AHP method & RA \\
\hline B1 & 1 & 7 & 7 & 5.000 \\
B2 & 3 & 8 & 9 & 6.667 \\
B3 & 2 & 13 & 13 & 9.333 \\
B4 & 4 & 10 & 8 & 7.333 \\
B5 & 6 & 9 & 11 & 12 \\
B6 & 9 & 5 & 1 & 9.667 \\
B7 & 7 & 12 & 10 & 5.000 \\
D1 & 4 & 6 & 12 & 9.667 \\
D2 & 8 & 3 & 6 & 9.000 \\
D3 & 13 & 4 & 3 & 6.667 \\
D4 & 11 & 1 & 5 & 13 \\
D5 & 10 & 2 & 4 & 6.333 \\
D6 & 12 & 2 & 6.667 \\
\end{tabular}

TABLE 23: Final ranking based on the Borda method.

\begin{tabular}{ccccccccccccccccccc}
\hline & AHP & TOPSIS-AHP & COPRAS-AHP & B1 & B2 & B3 & B4 & B5 & B6 & B7 & D1 & D2 & D3 & D4 & D5 & D6 & Domination & Rank \\
\hline B1 & 1 & 7 & 7 & 0 & 1 & 1 & 1 & 1 & 0 & 1 & 1 & 0 & 0 & 0 & 0 & 0 & 6 & 7 \\
B2 & 3 & 8 & 9 & 0 & 0 & 1 & 1 & 1 & 0 & 1 & 1 & 0 & 0 & 0 & 0 & 0 & 5 & 8 \\
B3 & 2 & 13 & 13 & 0 & 0 & 0 & 0 & 0 & 0 & 0 & 0 & 0 & 0 & 0 & 0 & 0 & 0 & 13 \\
B4 & 4 & 10 & 8 & 0 & 0 & 1 & 0 & 1 & 0 & 1 & 1 & 0 & 0 & 0 & 0 & 0 & 4 & 9 \\
B5 & 6 & 9 & 11 & 0 & 0 & 1 & 0 & 0 & 0 & 1 & 1 & 0 & 0 & 0 & 0 & 0 & 3 & 10 \\
B6 & 9 & 5 & 1 & 1 & 1 & 1 & 1 & 1 & 0 & 1 & 1 & 1 & 1 & 1 & 1 & 1 & 12 & 1 \\
B7 & 7 & 12 & 12 & 0 & 0 & 1 & 0 & 0 & 0 & 0 & 0 & 0 & 0 & 0 & 0 & 0 & 1 & 12 \\
D1 & 4 & 11 & 6 & 1 & 1 & 1 & 1 & 1 & 0 & 1 & 1 & 0 & 0 & 0 & 0 & 0 & 7 \\
D2 & 8 & 6 & 3 & 1 & 1 & 1 & 1 & 1 & 0 & 1 & 1 & 1 & 0 & 1 & 0 & 0 & 9 \\
D3 & 13 & 3 & 5 & 1 & 1 & 1 & 1 & 1 & 0 & 1 & 1 & 1 & 0 & 0 & 0 & 0 & 8 & 4 \\
D4 & 11 & 4 & 4 & 1 & 1 & 1 & 1 & 1 & 0 & 1 & 1 & 1 & 1 & 1 & 0 & 1 & 11 & 5 \\
D5 & 10 & 1 & 2 & 1 & 1 & 1 & 1 & 1 & 0 & 1 & 1 & 1 & 1 & 1 & 0 & 0 & 11 \\
D6 & 12 & 2 & & 2 & 1 & 0 & 0 & 0 & 1 & 0 & 0 & 0 & 0 & 0 & 0 & 2 \\
\hline
\end{tabular}


TABLE 24: Final ranking based on the Copeland method.

\begin{tabular}{ccccccccccccccccccccc}
\hline & AHP & TOPSIS-AHP & COPRAS-AHP & Alts & B1 & B2 & B3 & B4 & B5 & B6 & B7 & D1 & D2 & D3 & D4 & D5 & D6 & Dominate & Difference & Rank \\
\hline B1 & 1 & 7 & 7 & B1 & 0 & 1 & 1 & 1 & 1 & 0 & 1 & 1 & 0 & 0 & 0 & 0 & 0 & 6 & 0 \\
B2 & 3 & 8 & 9 & B2 & 0 & 0 & 1 & 1 & 1 & 0 & 1 & 1 & 0 & 0 & 0 & 0 & 0 & 5 & -2 \\
B3 & 2 & 13 & 13 & B3 & 0 & 0 & 0 & 0 & 0 & 0 & 0 & 0 & 0 & 0 & 0 & 0 & 0 & 0 & -12 & 13 \\
B4 & 4 & 10 & 8 & B4 & 0 & 0 & 1 & 0 & 1 & 0 & 1 & 1 & 0 & 0 & 0 & 0 & 0 & 4 & -4 \\
B5 & 6 & 9 & 11 & B5 & 0 & 0 & 1 & 0 & 0 & 0 & 1 & 1 & 0 & 0 & 0 & 0 & 0 & 3 & -6 & 10 \\
B6 & 9 & 5 & 1 & B6 & 1 & 1 & 1 & 1 & 1 & 0 & 1 & 1 & 1 & 1 & 1 & 1 & 1 & 12 & 12 & 1 \\
B7 & 7 & 12 & 10 & B7 & 0 & 0 & 1 & 0 & 0 & 0 & 0 & 0 & 0 & 0 & 0 & 0 & 0 & 1 & -10 & 12 \\
D1 & 4 & 11 & 12 & D1 & 0 & 0 & 1 & 0 & 0 & 0 & 1 & 0 & 0 & 0 & 0 & 0 & 0 & 2 & -8 \\
D2 & 8 & 6 & 6 & D2 & 1 & 1 & 1 & 1 & 1 & 0 & 1 & 1 & 0 & 0 & 0 & 0 & 0 & 7 & 11 \\
D3 & 13 & 3 & 3 & D3 & 1 & 1 & 1 & 1 & 1 & 0 & 1 & 1 & 1 & 0 & 1 & 0 & 0 & 9 & 6 \\
D4 & 11 & 4 & 5 & D4 & 1 & 1 & 1 & 1 & 1 & 0 & 1 & 1 & 1 & 0 & 0 & 0 & 0 & 8 & 4 \\
D5 & 10 & 1 & 4 & D5 & 1 & 1 & 1 & 1 & 1 & 0 & 1 & 1 & 1 & 1 & 1 & 0 & 1 & 11 & 1 \\
D6 & 12 & 2 & 2 & D6 & 1 & 1 & 1 & 1 & 1 & 0 & 1 & 1 & 1 & 1 & 1 & 0 & 0 & 10 & 5 \\
\hline
\end{tabular}

\section{Discussion and Conclusions}

The present study identified barriers and drivers in sustainable food supply chain implementation by reviewing the literature and interviewing and surveying industrial experts and constructing a bilevel hierarchy of criteria and subcriteria. The hierarchy is based on an objective of sustainability with economic, environmental, and social dimensions. Sales enhancement and cost reduction were found to be the most important economic factors. Moreover, water consumption management, greenhouse emission reduction, and water and soil contamination reduction were identified as the most important environmental factors, whereas localization, employment, and health level enhancement were the most important social factors. Finally, a total of 13 drivers and barriers were identified, including seven barriers and six drivers.

To rank the 13 barriers and drivers in sustainable food supply chain implementation, the MCDM approach is adopted. The experts were asked to respond to the questions. Through the expert views, the AHP, TOPSIS-AHP, and COPRAS-AHP methods were applied. Since these methods might yield different ranks, the present study employed ranking integration techniques, including the average weight, Borda, and Copeland techniques.

The results revealed that the economic criterion is more important than the environmental and social criteria. Sales enhancement, cost reduction, water consumption reduction, and health enhancement in society had the largest weights among the subcriteria. Distrust of consumers, lack of understanding and awareness of managers, and performance appraisal problems were found to be the most important barriers. Furthermore, informing the community by the media, entering the global market, exporting products, and producing sustainable products as a competitive advantage were identified to be the most important drivers. The results also showed that public awareness and demands would push the food supply chain toward sustainability, and the cooperation of the government and supplies could result in a sustainable food supply chain.

Based on the ranks derived from expert views, the present work provides implications and managerial insights for food supply chain managers and authorities, including the following:

(i) Managers need to improve their understanding and awareness to utilize scientific solutions and valid techniques in the sustainable food supply chain to enhance the supply chain in sustainability.

(ii) There are some products with misleading green and sustainable labels. This leads to consumer confusion and distrust. As a result, the government should intervene and prevent the sales of such products by supervision and control organizations and penalize the sellers of these products.

(iii) Performance appraisal problems were found as the third most important barrier. Does the implementation of a sustainable food supply chain bring environmental, economic, and social improvements? To answer this question, supply chain managers need to use an integrated information system that can derive proper feedback on the implementation. This requires financial and technological support from the government so that food supply chain sustainability could be implemented in a targeted manner to improve economic growth, welfare, and social health.

(iv) The cooperation and coordination of supply chain managers are necessary for sustainable food supply chain implementation. By cooperating with the government, supply chain managers can collectively deal with the implementation of a sustainable food supply chain in the form of associations and share their knowledge, experience, and skills to move toward proper sustainability implementation. However, there are problems such as distrust and the loss of competitive advantage, which can be solved by government oversight.

(v) Informing the advantages of sustainable products is found as the most important driver. Thus, the government can encourage the public to utilize sustainable food by informing through the media. Improving public awareness and demands would 
make the food supply chain take steps toward the implementation of sustainability.

The present work has limitations that can be tackled in the future. The limitations included difficulties in the distribution of questionnaires and refusals to respond. Also, experts were not easily accessible as several questionnaires need to be responded to. Therefore, we propose several suggestions for future research and researchers:

(i) Investigate the weights of the criteria and subcriteria using the analytic network process (ANP) to identify decision-making priorities of multiple variables without establishing one-way hierarchical relationship among decision levels

(ii) Identify and rank barriers and drivers in the supply chains of other products and use other MCDM techniques

(iii) Extend the statistical population to other Iranian provinces producing rice

\section{Data Availability}

The data used to support the findings of this study are included within the article.

\section{Conflicts of Interest}

The authors declare that there are no conflicts of interest.

\section{Authors' Contributions}

S. M. designed the model and analyzed the data. K. B. wrote the original manuscript. K. B. and S. M. assisted with manuscript preparation. Conceptualization was done by K. B.; methodology was done by S. M.; validation was done by S. M., K. B, and J. P.; original draft preparation was done by K. B.; review and editing were done by K. B. and J. P. All authors have read and agreed to the published version of the manuscript.

\section{Acknowledgments}

The authors would like to thank Ministry of Agriculture JIHAD for allowing them to implement the proposed model on this company. They also appreciate the company for providing the required data and information.

\section{References}

[1] K. Baghizadeh, N. Cheikhrouhou, K. Govindan, and M. Ziyarati, "Sustainable agriculture supply chain network design considering water-energy-food nexus using queuing system: a hybrid robust possibilistic programming," Natural Resource Modeling, vol. 35, Article ID e12337, 2021.

[2] A. Fredriksson and K. Liljestrand, "Capturing food logistics: a literature review and research agenda," International Journal of Logistics Research and Applications, vol. 18, no. 1, pp. 16-34, 2015.
[3] S. Gokarn and T. S. Kuthambalayan, "Analysis of challenges inhibiting the reduction of waste in food supply chain," Journal of Cleaner Production, vol. 168, pp. 595-604, 2017.

[4] L. Unnevehr, "Food safety in developing countries: moving beyond exports," Global Food Security, Elsevier B.V., vol. 4, pp. 24-29, 2015.

[5] F. Sgarbossa and I. Russo, "A proactive model in sustainable food supply chain: insight from a case study," International Journal of Production Economics, vol. 183, pp. 596-606, 2017.

[6] N. Duque Ciceri, M. Garetti, and S. Sperandio, "From product end-of-life sustainable considerations to design management," IFIP Advances in Information and Communication Technology, vol. 338, pp. 152-159, 2010.

[7] C. R. Carter and D. S. Rogers, "A framework of sustainable supply chain management: moving toward new theory," International Journal of Physical Distribution \& Logistics Management, Emerald Group Publishing Limited, vol. 38, no. 5, pp. 360-387, 2008.

[8] S. Seuring and M. Müller, "From a literature review to a conceptual framework for sustainable supply chain management," Journal of Cleaner Production, vol. 16, no. 15, pp. 1699-1710, 2008.

[9] H. Cañas, J. Mula, and F. Campuzano-Bolarín, "A general outline of a sustainable supply chain 4.0," Sustainability, vol. 12, no. 19, p. 7978, 2020.

[10] G. Egilmez, M. Kucukvar, O. Tatari, and M. K. S. Bhutta, "Supply chain sustainability assessment of the U.S. food manufacturing sectors: a life cycle-based Frontier approach," Resources, Conservation and Recycling, vol. 82, pp. 8-20, 2014.

[11] A. M. Sharif and Z. Irani, "People, process and policy perspectives on food security," Transforming Government: People, Process and Policy, vol. 10, no. 3, pp. 359-367, 2016.

[12] P. Beske and S. Seuring, "Putting sustainability into supply chain management," Supply Chain Management: International Journal, vol. 19, no. 3, pp. 322-331, 2014.

[13] M. Lezoche, J. E. Hernandez, M. d. M. E. Alemany Díaz, H. Panetto, and J. Kacprzyk, "Agri-food 4.0: a survey of the supply chains and technologies for the future agriculture," Computers in Industry, vol. 117, Article ID 103187, 2020.

[14] M. A. Ganie, N. Raizada, H. Chawla, A. K. Singh, S. Aggarwala, and C. S. Bal, "Primary hyperparathyroidism may masquerade as rickets-osteomalacia in Vitamin D replete children," Journal of Pediatric Endocrinology \& Metabolism: Journal of Pediatric Endocrinology \& Metabolism, vol. 29, no. 10, pp. 1207-1213, 2016.

[15] A. Kumar, A. Moktadir, Z. R. Liman, A. Gunasekaran, K. Hegemann, and S. A. Rehman Khan, "Evaluating sustainable drivers for social responsibility in the context of ready-made garments supply chain," Journal of Cleaner Production, vol. 248, Article ID 119231, 2020.

[16] K. Malik, S. M. Rahman, A. N. Khondaker, I. R. Abubakar, Y. A. Aina, and M. A. Hasan, "Renewable energy utilization to promote sustainability in GCC countries: policies, drivers, and barriers," Environmental Science and Pollution Research, vol. 26, no. 20, Article ID 20798, 2019.

[17] H. Hofmann, C. Busse, C. Bode, and M. Henke, "Sustainability-related supply chain risks: conceptualization and management," Business Strategy and the Environment, vol. 23, no. 3, pp. 160-172, 2014.

[18] M. A. Massoud, R. Fayad, M. El-Fadel, and R. Kamleh, "Drivers, barriers and incentives to implementing environmental management systems in the food industry: a case of Lebanon," Journal of Cleaner Production, vol. 18, no. 3, pp. 200-209, 2010. 
[19] S. Einwiller, B. Lis, C. Ruppel, and S. Sen, "When CSR-based identification backfires: testing the effects of CSR-related negative publicity," Journal of Business Research, vol. 104, pp. 1-13, 2019.

[20] S. Sugsaisakon and S. Kittipongvises, "Citywide energy-related $\mathrm{CO} 2$ emissions and sustainability assessment of the development of low-carbon policy in chiang mai, Thailand," Sustainability, vol. 13, no. 12, 2021.

[21] D. Kumar and Z. Rahman, "Sustainability adoption through buyer supplier relationship across supply chain: a literature review and conceptual framework," Int. Strateg. Manag. Rev.vol. 3, no. 1-2, pp. 110-127, 2015.

[22] J. D. Bloom, "Standards for development: food safety and sustainability in wal-mart's Honduran produce supply chains," Rural Sociology, vol. 80, no. 2, pp. 198-227, 2015.

[23] G. I. Doukidis, A. Matopoulos, M. Vlachopoulou, V. Manthou, and B. Manos, "A conceptual framework for supply chain collaboration: empirical evidence from the agrifood industry," Supply Chain Management: An International Journal, vol. 12, no. 3, pp. 177-186, 2007.

[24] S. Tomasiello and Z. Alijani, "Fuzzy-based approaches for agri-food supply chains: a mini-review," Soft Computing, vol. 25, no. 11, pp. 7479-7492, 2021.

[25] A. Ghadge, M. Er Kara, D. G. Mogale, S. Choudhary, and S. Dani, "Sustainability implementation challenges in food supply chains: a case of UK artisan cheese producers," Production Planning \& Control, vol. 32, no. 14, pp. 1191-1206, 2020.

[26] E. Bottani, G. Casella, M. Nobili, and L. Tebaldi, “Assessment of the economic and environmental sustainability of a food cold supply chain," IFAC-PapersOnLine, vol. 52, no. 13, pp. 367-372, 2019.

[27] H. K. Salim, R. Padfield, C. T. Lee, K. Syayuti, E. Papargyropoulou, and M. H. Tham, "An investigation of the drivers, barriers, and incentives for environmental management systems in the Malaysian food and beverage industry," Clean Technologies and Environmental Policy, vol. 20, no. 3, pp. 529-538, 2018.

[28] W. Hadikurniawati, E. Winarno, D. B. Santoso, and Purwatiningtyas, "A mixed method using AHP-TOPSIS for dryland agriculture crops selection problem," in Proceedings of the 2019 3rd International Conference on Informatics and Computational Sciences (ICICoS), Semarang, Indonesia, October 2019.

[29] K. Almutairi, A. Mostafaeipour, E. Jahanshahi, and E. Jouyandeh, "Ranking locations for hydrogen production using hybrid wind-solar: a case study," Sustainable Times, vol. 13 , no. 8, 2021.

[30] H. Allaoui, Y. Guo, and J. Sarkis, "Decision support for collaboration planning in sustainable supply chains," Journal of Cleaner Production, vol. 229, pp. 761-774, 2019.

[31] L. L. J. Meijer, J. C. C. M. Huijben, A. Van Boxstael, and A. G. L. Romme, "Barriers and drivers for technology commercialization by SMEs in the Dutch sustainable energy sector," Renewable and Sustainable Energy Reviews, vol. 112, pp. 114-126, 2019.

[32] O. Chkanikova and O. Mont, "Corporate supply chain responsibility: drivers and barriers for sustainable food retailing," Corporate Social Responsibility and Environmental Management, vol. 22, no. 2, pp. 65-82, 2015.

[33] M. Agyemang, Q. Zhu, M. Adzanyo, E. Antarciuc, and S. Zhao, "Evaluating barriers to green supply chain redesign and implementation of related practices in the West Africa cashew industry," Resources, Conservation and Recycling, vol. 136, pp. 209-222, 2018.

[34] A. Sajjad, G. Eweje, and D. Tappin, "Managerial perspectives on drivers for and barriers to sustainable supply chain management implementation: evidence from New Zealand," Business Strategy and the Environment, vol. 29, no. 2, pp. 592-604, 2020.

[35] S. Mithun Ali, M. A. Moktadir, G. Kabir, J. Chakma, M. J. U. Rumi, and M. T. Islam, "Framework for evaluating risks in food supply chain: implications in food wastage reduction," Journal of Cleaner Production, vol. 228, pp. 786-800, 2019.

[36] A. Mehmood, S. Ahmed, E. Viza, A. Bogush, and R. M. Ayyub, "Drivers and barriers towards circular economy in agri-food supply chain: a review," Business Strategy \& Development, vol. 4, no. 4, pp. 465-481, 2021.

[37] A. Hebinck, Z. Monika, A. Thom et al., "A Sustainability Compass for policy navigation to sustainable food systems," Glob. Food Sec., vol. 29, Article ID 100546, 2021.

[38] O. Narimissa, A. Kangarani-Farahani, and S. Molla-AlizadehZavardehi, "Drivers and barriers for implementation and improvement of sustainable supply chain management," Sustainable Development, vol. 28, no. 1, pp. 247-258, 2020.

[39] S. Luthra, S. K. Mangla, L. Xu, and A. Diabat, "Using AHP to evaluate barriers in adopting sustainable consumption and production initiatives in a supply chain," International Journal of Production Economics, vol. 181, pp. 342-349, 2016.

[40] J. D. Darbari, V. Agarwal, R. Sharma, and P. C. Jha, Analysis of Impediments to Sustainability in the Food Supply Chain: An Interpretive Structural Modeling Approach, Springer, Berlin, Germany, 2018.

[41] B. Notarnicola, K. Hayashi, M. A. Curran, and D. Huisingh, "Progress in working towards a more sustainable agri-food industry," Journal of Cleaner Production, vol. 28, pp. 1-8, 2012.

[42] S. K. Mangla, S. Luthra, N. Rich, D. Kumar, N. P. Rana, and Y. K. Dwivedi, "Enablers to implement sustainable initiatives in agri-food supply chains," International Journal of Production Economics, vol. 203, pp. 379-393, 2018.

[43] H. Walker and N. Jones, "Sustainable supply chain management across the UK private sector," Supply Chain Management, vol. 17, no. 1, pp. 15-28, 2012.

[44] S. Bhaskaran, M. Polonsky, J. Cary, and S. Fernandez, "Environmentally sustainable food production and marketing: opportunity or hype?" British Food Journal, Uplands Press (Emerald), vol. 108, no. 8, pp. 677-690, 2006.

[45] G. B. Simpson and G. P. W. Jewitt, "The development of the water-energy-food nexus as a framework for achieving resource security: a review," Frontiers of Environmental Science, vol. 7, no. FEB, p. 8, 2019.

[46] A. Del Borghi, M. Gallo, C. Strazza, and M. Del Borghi, "An evaluation of environmental sustainability in the food industry through Life Cycle Assessment: the case study of tomato products supply chain," Journal of Cleaner Production, vol. 78, pp. 121-130, 2014.

[47] M. Canavari, Summary Report on Sensory-Related SocioEconomic and Sensory Science Literature about Organic Food Products, Alma Mater Studiorum-University of Bologna, Bologna, Italy, 2009.

[48] K. Baghizadeh, J. Pahl, and G. Hu, "Closed-loop supply chain design with sustainability aspects and network resilience under uncertainty: modelling and application," Mathematical Problems in Engineering, vol. 2021, Article ID 9951220, 23 pages, 2021. 
[49] B. G. Smith, "Developing sustainable food supply chains," Philosophical Transactions of the Royal Society B: Biological Sciences, Royal Society, vol. 363, no. 1492, pp. 849-861, 2008.

[50] G. Svensson and B. Wagner, "Implementation of a sustainable business cycle: the case of a Swedish dairy producer," Supply Chain Management, vol. 17, no. 1, pp. 93-97, 2012.

[51] V. P. Sharma and V. Paul, "India's agricultural development under the new economic regime: policy perspective and strategy for the 12th five year plan," Indian Journal of Agricultural Economics, vol. 67, 2011 https://ideas.repec.org/p/ iim/iimawp/10681.html.

[52] A. Diabat, G. Kannan, and V. Panikar, "Supply chain risk management and its mitigation IN a food industry," International Journal of Production Research, vol. 50, 2011.

[53] R. Sharma, S. S. Kamble, and A. Gunasekaran, "Big GIS analytics framework for agriculture supply chains: a literature review identifying the current trends and future perspectives," Computers and Electronics in Agriculture, Elsevier B.V., vol. 155, pp. 103-120, 2018.

[54] N. Deepa, K. Ganesan, K. Srinivasan, and C. Y. Chang, "Realizing sustainable development via modified integrated weighting MCDM model for Ranking Agrarian Dataset," Sustainable Times, vol. 11, no. 21, 2019.

[55] C. Peng, H. Du, and T. Warren Liao, "A research on the cutting database system based on machining features and TOPSIS," Robotics and Computer-Integrated Manufacturing, vol. 43, pp. 96-104, 2017. 